INEEL/EXT-01-00046

February 2001

\title{
Evaluation of Confining Layer Integrity Beneath the South District Wastewater Treatment Plant, Miami-Dade Water and Sewer Department, Dade County, Florida
}

R. C. Starr

T. S. Green

L. C. Hull 


\title{
Evaluation of Confining Layer Integrity Beneath the South District Wastewater Treatment Plant, Miami-Dade Water and Sewer Department, Dade County, Florida
}

\author{
Robert C. Starr \\ Timothy S. Green \\ Laurence C. Hull
}

Published February 2001

Idaho National Engineering and Environmental Laboratory

Geosciences Research Department Idaho Falls, Idaho 83415

\section{Prepared for the}

U.S. EPA National Exposure Research Laboratory, Technology Support Center, Characterization and Monitoring Branch and for the

U.S. Department of Energy

Assistant Secretary for Environmental Management

Under DOE Idaho Operations Office

Contract DE-AC07-99ID13727 


\section{ABSTRACT}

A review has been performed of existing information that describes geology, hydrogeology, and geochemistry at the South District Wastewater Treatment Plant, which is operated by the Miami-Dade Water and Sewer Department, in Dade County, Florida. Treated sanitary wastewater is injected into a saline aquifer beneath the plant. Detection of contaminants commonly associated with treated sanitary wastewater in the freshwater aquifer that overlies the saline aquifer has indicated a need for a reevaluation of the ability of the confining layer above the saline aquifer to prevent fluid migration into the overlying freshwater aquifer. Review of the available data shows that the geologic data set is not sufficient to demonstrate that a competent confining layer is present between the saline and freshwater aquifers. The hydrogeologic data also do not indicate that a competent confining layer is present. The geochemical data show that the freshwater aquifer is contaminated with treated wastewater, and the spatial patterns of contamination are consistent with upward migration through localized conduits through the Middle Confining Unit, such as leaking wells or natural features. Recommendations for collection and interpretation of additional site characterization data are provided. 


\section{SUMMARY}

Treated wastewater is disposed in a saline aquifer beneath the South District Wastewater Treatment Plant (SDWTP), operated by the Miami Dade Water and Sewer Department, in Dade County, Florida. The saline aquifer is separated from the overlying freshwater aquifer by the Middle Confining Unit (MCU). Detection of contaminants commonly associated with treated sanitary wastewater in the freshwater aquifer has caused the integrity of the MCU, i.e. its ability to prevent migration from the zone of injection into the overlying freshwater aquifer, to be questioned.

The United States Environmental Protection Agency - Region 4 requested that the Idaho National Engineering and Environmental Laboratory (INEEL) review available information that describe the geology, hydrogeology, and geochemistry at the SDWTP, and to assess whether these data are sufficient for evaluating the integrity of the MCU.

The geologic information provided for review are not sufficient to conclude that the MCU is competent to prevent migration of injected wastewater from the saline aquifer into the overlying freshwater aquifer. Additional data collection and interpretation activities are recommended.

The hydrogeologic information provided indicate that the hydraulic head gradient would tend to cause fluids to migrate upward from the saline aquifer into the overlying freshwater aquifer. Although the site-specific hydraulic test data show that the rocks that overlie the zone of injection have lower hydraulic conductivity (i.e. are less permeable) than those in the saline aquifer, the values measured for these materials are much higher than typical values for confining units. Conservative calculations of the upward fluid flux from the saline aquifer indicate that a substantial volume of injected wastewater could migrate into the overlying freshwater aquifer. These results indicate that the MCU is not a competent confining layer. A caveat to this interpretation is that the hydraulic characterization test methods employed may not adequately represent the less permeable hydrostratigraphic units, and hence the hydraulic data set may not adequately describe the actual site conditions. Recommendations are provided for additional studies to improve the hydrogeologic characterization of the site.

The geochemical data provided indicate that treated wastewater is present in the freshwater aquifer overlying the saline aquifer used for wastewater disposal, which indicates that pathways that allow migration of wastewater from the saline aquifer to the overlying freshwater aquifer must exist. The spatial patterns of contamination suggest that upward migration occurs along localized pathways such as wells that are not adequately sealed or natural conduits.

Although it is clear that the freshwater aquifer is contaminated with treated wastewater injected into the saline aquifer, there is a discrepancy between the migration pathways that would be inferred from the results of the hydrogeologic and geochemical evaluations. The hydrogeologic data reviewed suggest that upward migration could occur on a site-wide basis. The geochemical data reviewed suggest that contaminant migration occurs through localized conduits. This discrepancy may be resolved through improved geologic and hydrogeologic characterization of the subsurface beneath the SDWTP.

In summary, the information reviewed is not sufficient to conclude that the MCU is a competent confining unit. The presence of treated wastewater in the freshwater aquifer above the MCU could result from migration through either inadequately sealed wells or through natural conduits through the MCU. In order to further evaluate the integrity of the MCU and to build a case that it is in fact a competent confining layer and that wells provide the only contaminant migration pathways, additional geologic and hydrogeologic characterization data must be collected and interpreted. Recommendations for an additional characterization program are provided. 


\section{CONTENTS}

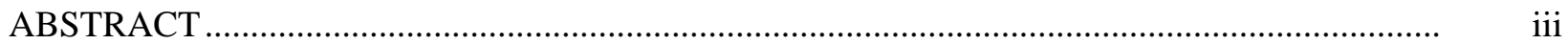

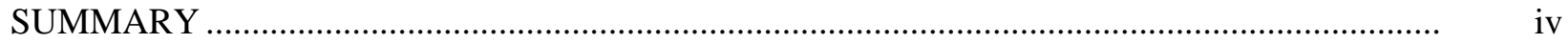

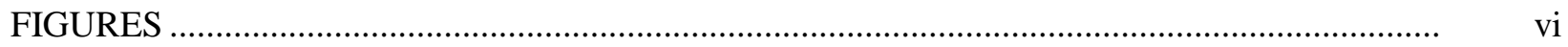

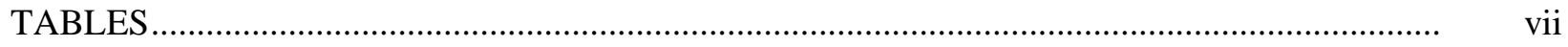

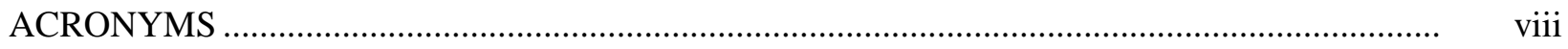

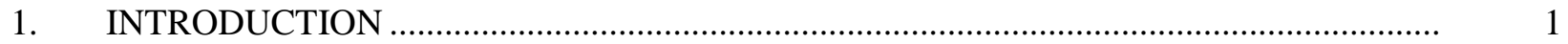

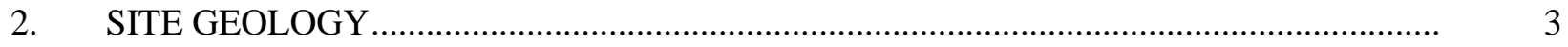

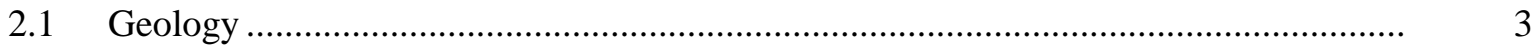

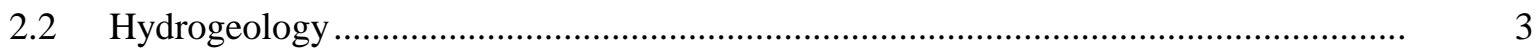

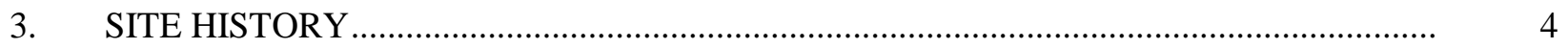

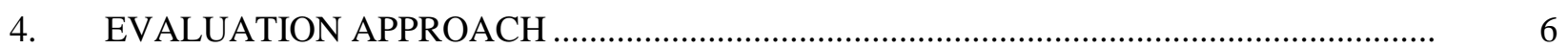

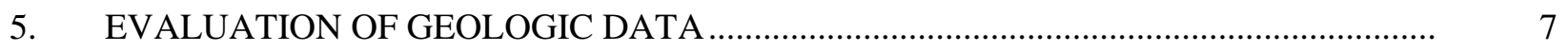

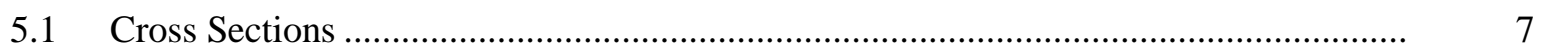

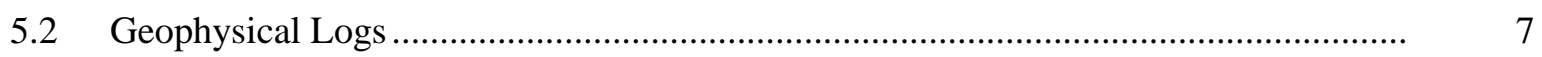

5.3 Mechanical Integrity Tests and Radioactive Tracer Tests....................................... 8

5.4 Geologic Conclusions and Recommendations …................................................

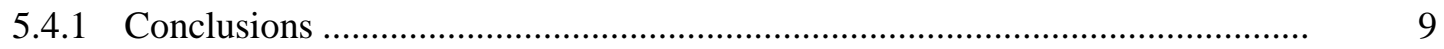

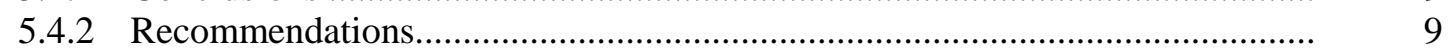

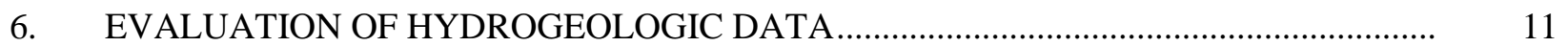

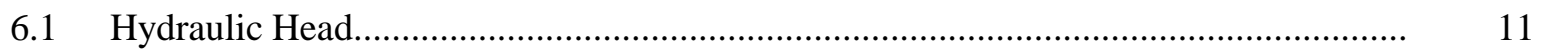

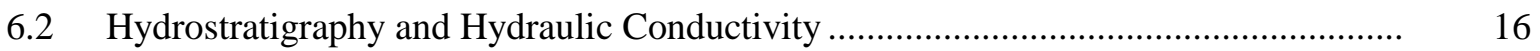

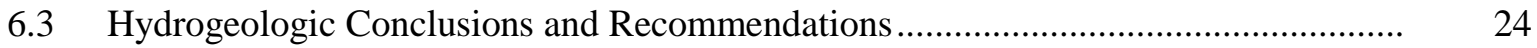

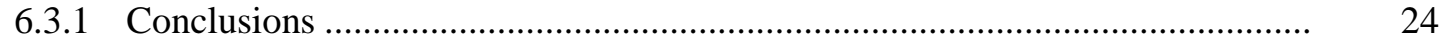

6.3.2 Recommendations.................................................................................... 26

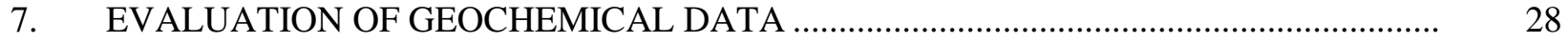

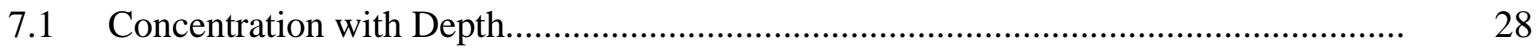




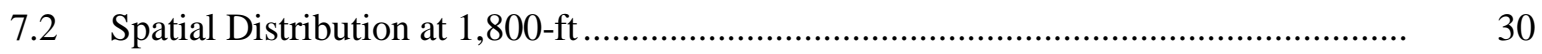

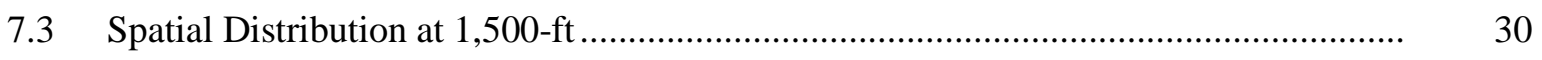

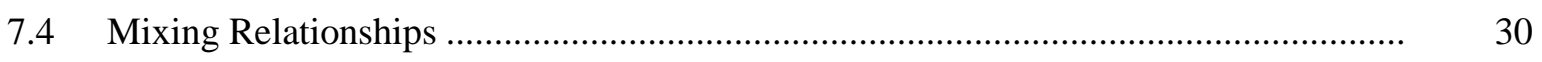

7.5 Geochemical Conclusions and Recommendations .................................................. 36

8. SUMMARY OF CONCLUSIONS AND RECOMMENDATIONS...................................... 38

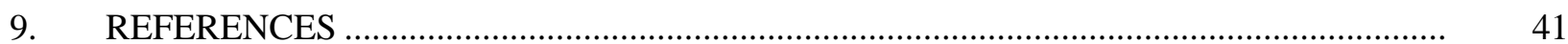

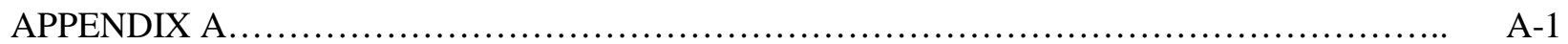

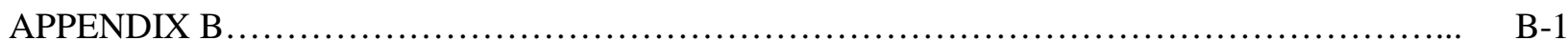

\section{FIGURES}

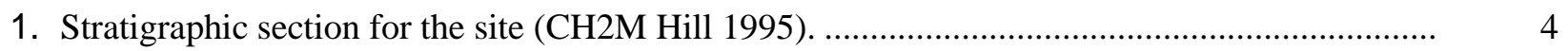

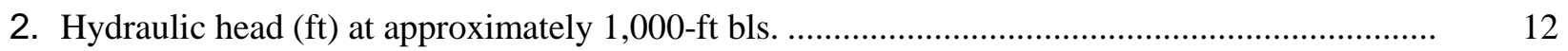

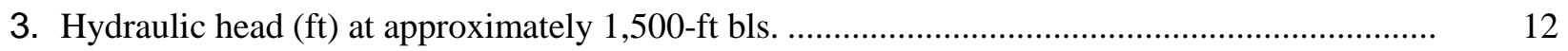

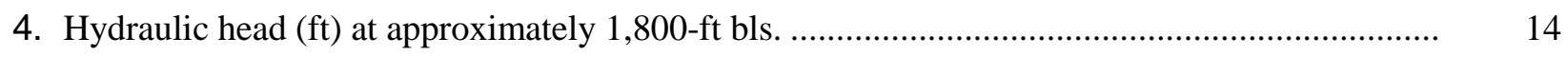

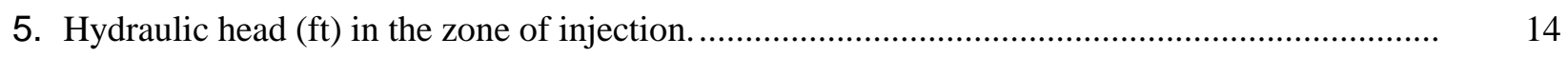

6. Hydraulic test data from Singh, Garcia-Bengochea, and Sproul (1980) and MDWSD (1994).

7. Typical range of hydraulic properties of geologic materials (Freeze and Cherry 1979) and range of observed values at the SDWTP.

8. Effective vertical and horizontal hydraulic conductivity for a horizontally layered system (modified from Freeze and Cherry 1979).....

9. Plot of chloride concentration with depth for all wells

10. Plot of ammonia concentration with depth for all wells.

11. Map of wells completed in the $1,800-\mathrm{ft}$ depth zone.

12. Map of wells completed in the $1,800-\mathrm{ft}$ depth zone showing approximate completion depths (ft).

13. Map of the 1,800-ft depth zone showing the concentration of ammonia in wells.

14. Map of the 1,800-ft depth zone showing the concentration of chloride in wells.

15. Map of the 1,500-ft depth zone showing locations of monitoring wells. 
16. Map of the 1,500-ft depth zone showing depths of completion intervals ( $\mathrm{ft}$ ).

17. Map of the 1,500-ft depth zone showing the concentration of ammonia in monitoring wells.

. Map of the 1,500-ft depth zone showing the concentration of chloride in monitoring wells.........

19. Ternary diagram showing the evolution of groundwater at the site from the mixing of three components.

20. Graph of ammonia and bromide in groundwater samples.

\section{TABLES}

1. Hydraulic head at approximately 9,000 minutes (data from Rust 1998a)................................. 13

2. Hydraulic test data from Singh, Garcia-Bengochea, and Sproul (1980). ................................. 17

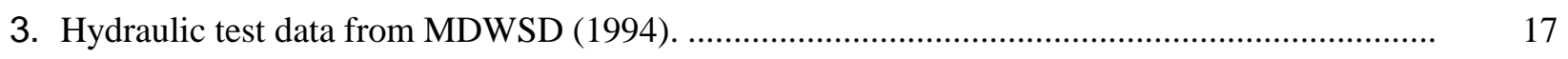

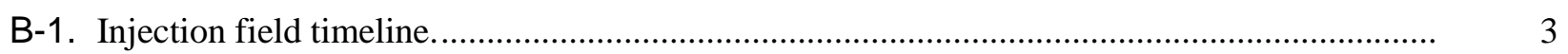




\section{ACRONYMS}

BZ Boulder Zone

CFR Code of Federal Regulations

EPA United States Environmental Protection Agency

FA Floridan Aquifer

GR Gamma-ray

INEEL Idaho National Engineering and Environmental Laboratory

IW Injection Well

MCU Middle Confining Unit

MDWSD Miami-Dade Water and Sewer Department

MIT Mechanical Integrity Test

SDWTP South District Wastewater Treatment Plant

UFA Upper Floridan Aquifer

UIC Underground Injection Control

USDW Underground Source of Drinking Water 


\section{INTRODUCTION}

This report describes an independent review of selected information pertaining to hydrogeologic conditions and subsurface contaminant migration at the Miami-Dade Water and Sewer Department South District Wastewater Treatment Plant (SDWTP) in Dade County, Florida. This review was requested by the U.S. Environmental Protection Agency (EPA) National Exposure Research Laboratory-Technology Support Center, on behalf of EPA Region 4, and was performed by the Idaho National Engineering and Environmental Laboratory (INEEL).

This report is organized as follows. This section is the introduction. Site geology and history are described in Sections 2 and 3, while Section 4 describes the review approach. The reviews of the geologic, hydrogeologic, and geochemical data sets are presented in Sections 5, 6, and 7 respectively. Section 8 presents conclusions and recommendations.

Beginning in 1983, treated sanitary wastewater was injected into a deep, saline aquifer beneath the SDWTP using a network of wells. When deep subsurface injection was selected, the hydrogeologic conditions at the site were believed to be suitable for waste disposal. However, contaminants commonly associated with treated sanitary wastewater have been detected in the freshwater aquifer above the saline aquifer. This has caused the suitability of the saline aquifer for wastewater disposal and the ability of the confining layer above the saline aquifer to isolate the freshwater aquifer from contamination to be questioned. The situation is complicated by the presence of injection wells and the former presence of monitoring wells that penetrate the confining unit; some of these wells have corroded casing or inadequate annular seals, and thus they may act as conduits for contaminant transport from the saline aquifer into the overlying freshwater aquifer.

In general, the purpose of this independent review is to determine whether the existing geologic, hydrogeologic, and geochemical data are sufficient to attribute the observed contamination above the zone of injection to either (a) movement only through inadequately sealed wells or (b) widespread movement through the confining layer.

The INEEL was provided with existing data from EPA Region 4 and asked to evaluate it. The documents that were evaluated are listed in Appendix A. (No additional data collection activities were performed as part of this evaluation). An INEEL project team was organized and used the date provided by the EPA to evaluate the following issues:

(1) Whether the existing data are sufficient to either prove or disprove the presence of a confining layer above the zone of injection and, if it is present, whether it is capable of preventing movement of injected fluids from the zone of injection into the overlying monitoring zones

(2) Whether the data sets support the Miami-Dade Water and Sewer Department's contention that all of the observed contamination of the monitoring zone could have resulted from vertical flow through unsealed boreholes

(3) If the data are not sufficient to evaluate points 1 and 2, identify the additional data that should be collected to provide definitive answers. 
Federal regulations pertaining to waste injection wells contained in 40 CFR 144 and 40 CFR 146:

- $\quad$ Prohibit the movement of injected fluids into underground sources of drinking water such as the Upper Floridan Aquifer (40 CFR 144.12 and 40 CFR 144.13(a)(1))

- $\quad$ Require that wells be constructed to prevent the movement of fluids into an underground source of drinking water (40 CFR 146.12(b))

- Require that the lithology of the confining layer be considered in well construction (40 CFR 146.12(b)(6))

- $\quad$ Require that appropriate logs be collected and tests be performed during drilling and construction of new Class I wells (40 CFR 146.12(d))

- Require that a subsurface water quality monitoring program be developed based on the potential for fluid migration in the subsurface (40 CFR 146.13(d)).

The overall intent of these regulations is to ensure that injection wells and associated monitoring wells are constructed and operated in a manner that does not allow fluids to move from the zone of injection into overlying underground sources of drinking water, and that a monitoring program is implemented to provide warning if such movement does occur. 


\section{SITE GEOLOGY}

The hydrogeology is setting of the SDWTP is briefly described in this section. An evaluation of the geologic data set is provided in Section 5.

\subsection{Geology}

This description of the geologic setting was taken primarily from the aquifer exemption petition (CH2M Hill 1995). Figure 1 was reproduced from this document. From ground surface downward, the geologic media include the following:

- $\quad$ Pleistocene age Miami Limestone and Fort Thompson Formation-Miami Limestone is sandy and oolitic with abundant shell fragments and highly permeable. The underlying Fort Thompson Formation is finer grained, with more sand and shell. The unconfined Biscayne Aquifer occurs in these materials.

- Miocene age Hawthorn Group - The Hawthorne Group consists of interbedded sand, silt, clay, dolostone, and limestone. The Hawthorn Group acts as an aquitard that confines the Upper Floridan Aquifer, and is referred to as the Upper Confining Unit.

- Oligocene age Suwannee limestone-Suwannee Limestone is the uppermost member of the Upper Floridan Aquifer.

- Eocene age Avon Park Limestone-Avon Park Limestone includes zones with high porosity $(50 \%)$, which probably act as water bearing units and low-permeability fine-grained units, which act as intra-aquifer confining units. Avon Park Limestone includes part of the Upper Floridan Aquifer and the Middle Confining Unit. The Middle Confining Unit hydraulically separates the Upper and Lower Floridan Aquifers. The Middle Confining Unit is not a lithologically distinct unit (e.g., a shale layer).

- $\quad$ Eocene age Oldsmar Limestone-Oldsmar Limestone consists primarily of limestone and dolostone. The lower portion of this unit is karstic. Oldsmar Limestone is part of the Lower Floridan Aquifer. A highly permeable portion of this unit, the Boulder Zone, is the zone of injection for treated wastewater.

\subsection{Hydrogeology}

Three cross sections through the South District Wastewater Treatment Plant site based on sitespecific data are presented in Rust (1998a). These sections show the portions of the hydrogeologic system at the site. The uppermost hydrogeologic unit, the Biscayne Aquifer,is underlain by the Upper Confining Unit. The Upper Floridan Aquifer underlies the Upper Confining Unit. The Upper Floridan Aquifer is the underground source of drinking water that concerns the EPA relative to the migration of contaminated water upward from the zone of injection. The Middle Confining Unit separates the overlying Upper Floridan Aquifer from the underlying Lower Floridan Aquifer. The focus of this evaluation is the ability of the Middle Confining Unit to prevent migration of injected wastewater from the Lower Floridan Aquifer to the Upper Floridan Aquifer. The Boulder Zone, a highly permeable portion of the Lower Floridan Aquifer, is used as the zone of injection beneath at the SDWTP.

The Upper Floridan Aquifer extends from approximately 1,000 to 1,900-ft below land surface (bls) at the SDWTP. The Middle Confining Unit extends from approximately 1,900 to 2,400-ft bls. The Lower Floridan Aquifer extends from approximately 2,400-ft bls to an undetermined depth. The Boulder Zone (the zone of injection) extends from approximately 2,800 to at least 3,000-ft bls at the SDWTP. 


\section{SITE HISTORY}

Appendix B contains a list of events relevant to this evaluation. This list was extracted from a variety of references provided by EPA Region 4 (see Appendix A). Events thought to be relevant to this evaluation are described in the following paragraphs.

A test hole was drilled at the site and used for hydraulic testing of the subsurface materials beneath the SDWTP. The results of this test program were published in 1980 in the peer-reviewed literature by Singh, Garcia-Bengochea, and Sproul (1980). Between 1979 and 1981, nine injection wells and three monitoring wells were installed. Injection of treated wastewater commenced in 1983. Additional injection and monitoring wells were installed between 1991 and 1996 to increase plant capacity.

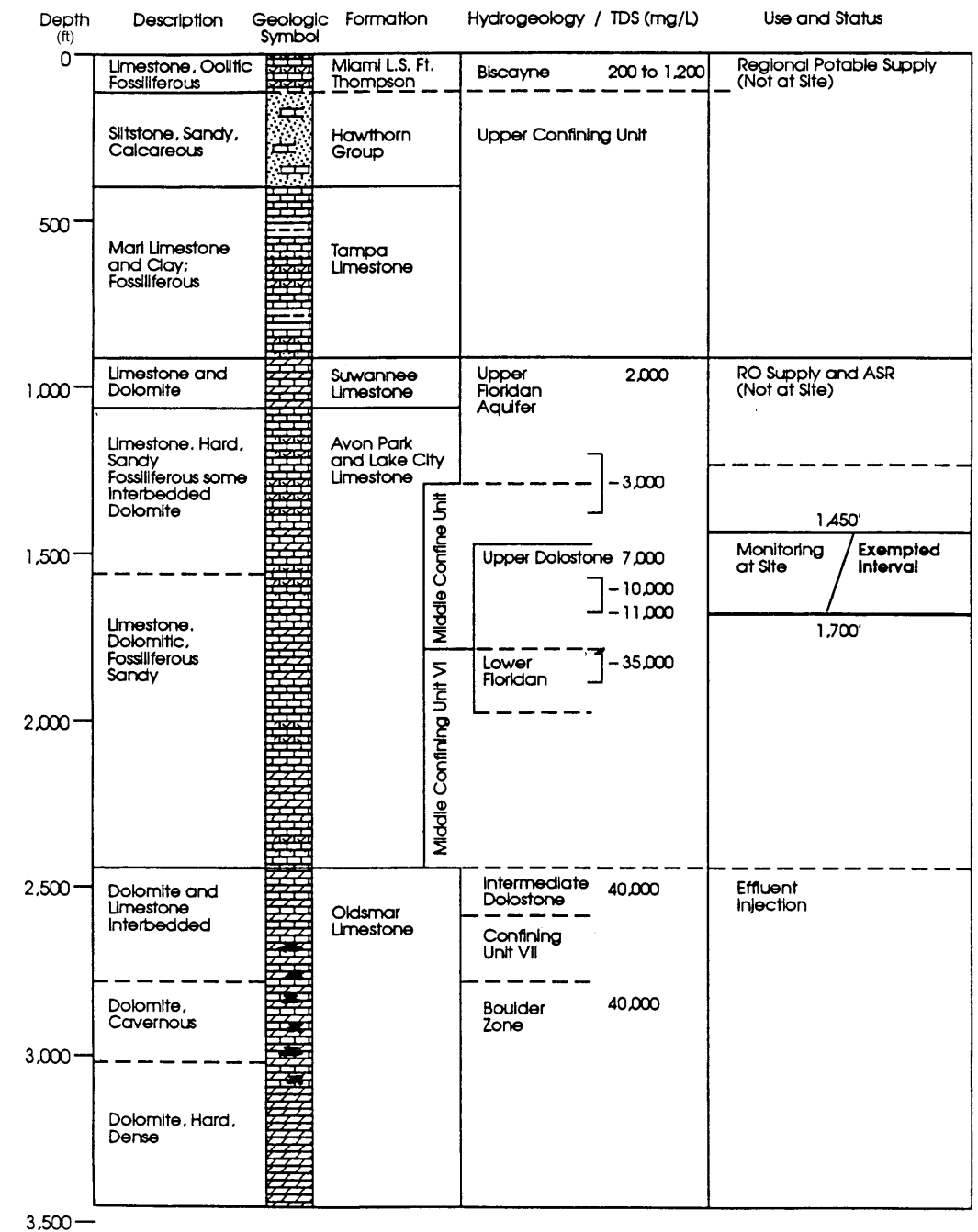

Figure 1. Stratigraphic section for the site (CH2M Hill 1995).

Between 1983 (when injection commenced) and 1994, there was no evidence that contaminated water was migrating upward from the zone of injection. However, during 1994, monitoring data from the wells suggested that contaminated water had migrated from the zone of injection into the lower portion of 
the Upper Floridan Aquifer. This evidence included the observation of elevated concentrations of ammonia and elevated counts of fecal coliform bacteria in samples collected from Wells FA-5 through FA-8 (Rust 1998b). Both ammonia and fecal coliform bacteria are indicators of contamination by sanitary sewage.

As discussed in Section 1, migration of fluids from the Boulder Zone through inadequately sealed wells has been suggested as the cause of contamination in the Upper Florida Aquifer. Problems with well integrity and construction that may have contributed to contaminant migration have been documented and are described below.

- $\quad$ BZ series of monitoring wells

In 1994, Monitoring Well BZ-3 was found to be corroded at a depth of approximately 1,500-ft bls (Rust 1998b), which is in the lower portion of the Upper Floridan Aquifer. The hydraulic head is higher in the zone of injection than in the Upper Floridan Aquifer (see Section 6.2); therefore, if this well were open both in the zone of injection and in the Upper Floridan Aquifer, groundwater would flow upward from the zone of injection, through the well, and out of the well into the Upper Floridan Aquifer. In 1995, Monitoring Wells BZ-3 (open depth of 2,434 to 2,474-ft) and BZ-4 (open depth of 2,689 to 2,960-ft) were plugged and reconfigured to monitor at depths of approximately 1,000 and 1,500-ft bls (Rust 1998b).

- $\quad$ Injection Well IW-2

In 1994, periodic inspection activities indicated that a 3-foot separation in the casing caused a leak in Well IW-2 at a depth of approximately 2,500-ft and that an obstruction was present at a depth of approximately 2,600-ft. It was reported that the radioactive tracer survey confirmed the mechanical integrity of the annular seal above a depth of 2,440-ft (MDWSD 1998). The obstruction was removed but apparently the separated casing was not repaired. In 1998, the separation in the casing had increased from 3 to 7 -ft. A pressure test indicated that the integrity of the casing above 2,435-ft was satisfactory, although tracer may have been detected behind the casing below approximately 2,320-ft (MDWSD 1998)

Although the mechanical integrity of the lower portion of the casing of IW-2 clearly was impaired, the reviewer's opinion is that this lack of integrity did not necessarily contribute to vertical migration of fluids out of the zone of injection because the casing separation occurred in the Lower Floridan Aquifer. However, if the annular seal were damaged or imperfect between the separated casing and the Upper Floridan Aquifer, then the unsealed annulus could provide a migration pathway from the Lower Floridan Aquifer to shallower parts of the system.

Based on the observation of ammonia and fecal coliform in the Upper Floridan Aquifer, vertical migration of fluids from the zone of injection through Well BZ and into the Middle Floridan Aquifer occurred prior to 1995. This migration may be partially responsible for the more recently observed contamination of the Middle Floridan Aquifer. 


\section{EVALUATION APPROACH}

The approach taken in this evaluation was to consider several types of data (lines of evidence) and to determine whether all data sets yield a consistent interpretation. Significant gaps in each data set, if present, were identified. Data were extracted from several reports provided by EPA Region 4. No new data were generated during this evaluation.

The types of data sets evaluated include the following:

- Geologic data such as lithology and stratigraphy

- $\quad$ Borehole geophysical logs

- Hydrogeologic data such as the hydraulic properties of various hydrostratigraphic units and hydraulic head

- Geochemical data such as concentrations of chloride, bromide, and ammonia.

Geologic and geophysical data were examined to evaluate whether there is sufficient evidence to conclude that the Middle Confining Unit is an effective barrier to contaminant migration between the Lower Floridan Aquifer and the Upper Floridan Aquifer. In particular, the geophysical logs provided were assessed to determine if the interpretation techniques used in the petroleum exploration and production industry can be used to infer geologic conditions at the SDWTP.

Hydrogeologic data (hydraulic head and hydraulic conductivity) were examined to determine the direction of groundwater flow (i.e., upward or downward), to calculate the specific discharge in the vertical direction, and to estimate the travel time of the water from the injection zone to the Upper Floridan Aquifer. The adequacy of the hydraulic properties data set also was assessed for making inferences about the competency of the Middle Confining Unit throughout the entire area affected by injection of wastewater beneath the SDWTP.

Chemical data were examined to determine whether spatial patterns characteristic of localized or widespread contaminant migration pathways were apparent in the data set. Mixing trends also were examined to determine whether the observed chemical composition indicate that treated effluent has migrated out of the zone of injection. 


\section{EVALUATION OF GEOLOGIC DATA}

Geologic data prepared by third parties and provided by EPA Region 4 were reviewed. A summary and set of recommendations are provided in Section 5.6.

The following information was examined:

- Geologic cross sections provided by third parties

- $\quad$ Federal and Florida underground injection control (UIC) regulations

- $\quad$ Geophysical logs

- $\quad$ Mechanical test (MIT) reports.

\subsection{Cross Sections}

There would appear to be little variation in lithology between the wells at the SDWTP site and the section is essentially flat laying with no evidence of large displacement faulting. The Gamma Ray (GR) response through the Hawthorn Group and Ocala Limestone indicates some lithologic variability and interbedding. The Avon Park Limestone (Upper Floridian Aquifer and Middle Confining Unit) appears to be fairly homogeneous. The exception is section B - B' (Rust 1998a, Figure 4-6) where the GR response in the Avon Park Limestone is more variable indicating a lessor degree of lithologic homogenity. The greatest amount of lithologic variability is displayed in the Oldsmar Formation (Injection Zone). This may be a relic of hole conditions, however, as the sonic log seems to indicate that the hole is washed out (enlarged) in some of the wells.

\subsection{Geophysical Logs}

Based on the INEEL interpretation of Florida Underground Injection Control (UIC) regulations (62-528.300 Underground Injection Control: General Provisions), the injection wells at the SDWTP are classified as Class I injection wells. If this interpretation is correct, then the additional data sets that are required by the State of Florida UIC permitting regulations should be made available so that standard geophysical techniques can be used to assess the properties of various hydrostratigraphic units. These data sets would include the following:

- $\quad$ Resistivity logs (complete set)

- $\quad$ Gamma-ray logs (complete set)

- $\quad$ Sonic logs

- $\quad$ Porosity and density logs

- $\quad$ Core samples

- $\quad$ Physical core analysis (permeability, porosity, and mineralogy). 
With these data sets, correlations could be made between core permeability data and the geophysical logs. Moreover, the only way a quantitative analysis of the Middle Confining Unit based on geophysical data can be performed with any degree of certainty is through such correlation.

The geophysical logs provided do not have adequate coverage of the Middle Confining Unit. The only well with a complete logging run was IW-17, and it was limited to a GR/resistivity log. In addition, it is not possible to perform an evaluation of the stratigraphy or physical attributes of the confining units without sonic and density logs.

\subsection{Mechanical Integrity Tests and Radioactive Tracer Tests}

The mechanical integrity tests performed on the casing in the two wells (IW-1 and IW-2) for which data were provided meet acceptable industry standards for pressure loss over time. However, the mechanical integrity tests evaluated only the casing but not the casing shoe (i.e., the bottom of the casing). Because the wells appear to be open-hole completion in the injection zone, an area of concern is the integrity of the annular seal at the shoe. The concern is especially true for IW-2, which suffered a casing failure that resulted in the casing slipping approximately 6 to 7 - $\mathrm{ft}$ from its original position (MDWSD 1998).

With respect to the radioactive tracer tests, if fluids and thus the tracer can migrate more easily in the horizontal plane at the casing shoe than up the annulus, it is possible that the gamma tool would not detect the tracer and, therefore, the tests could be considered invalid. Under this scenario, the tests conducted in both IW-1 and IW-2 would be invalid. In the analysis of the tracer test performed on IW-2, the Miami-Dade Water and Sewer Department (MDWSD) stated that the test was inconclusive at elevations above approximately 2,485-ft bls and that the tracer was detected behind the casing below approximately 2,320-ft bls (MDWSD 1998). The inconclusive result was referenced as an ambiguity in the report and consequently the report recommended that the test be repeated. Therefore, the original test should be considered invalid. In addition, in the same report, the MDWSD stated that the tracer "appeared" to be detected in the long-term monitoring of MW-FA-11, which is completed in the Upper Florida Aquifer. No explanation was given why it "appeared" to have been detected in the well in this portion of the report. However, in another part of the report, it is concluded that the test should be repeated to "determine the existence of the pathway connecting the injection zone to lower monitoring zone (below the USDW)" (MDWSD 1998).

A well to well tracer test was conducted by injecting tracer solution into IW-2 and extracting water from the adjacent monitoring well, FA-11, and monitoring for tracer arrival at that well. The equipment configuration in FA-11 included a downhole gamma detector and a submersible pump. The reviewers believe that both were installed at a shallow depth in the well and far above the screened or open interval of the well. The equipment schematic in the 1998 report (MDWSD 1998) shows that the gamma detector was located above the pump. This configuration is poorly suited for detecting changes in tracer concentration in groundwater extracted from the formation. Water would enter the bottom of the well and flow upward to the pump, and would then exit the well at the elevation of the pump intake. However, the water above the pump would be more or less stagnant, and its composition (and hence tracer concentration) would vary only as a result of mixing caused by turbulence in the casing in the vicinity of the pump. This mixing process is undoubtedly less effective than advection for displacing water in the casing with water freshly drawn from the formation. Therefore, changes in tracer concentration above the pump would be much smaller than changes in the aquifer and in the well below the pump.

Based on the equipment schematic presented in MDWSD (1998), the test is invalid. If interwell tracer tests are used again at the site, the tracer sensor should be placed between the bottom of the well and the pump intake. 


\subsection{Geologic Conclusions and Recommendations}

\subsubsection{Conclusions}

Demonstration of a geologic unit's ability to prevent upward migration of injected fluids is done through an analysis of stratigraphic, petrophyscial, and geochemical properties of the confining layer. These properties include lateral continuity of the unit, horizontal and vertical porosity and permeability, the presence/absence of faulting/fracturing within the confining layer, and waste compatibility with the confining layer. The review of the available geologic data set resulted in the conclusion that it is insufficient for performing this analysis and therefore the ability of the Middle Confining Unit to prevent upward migration of injected wastewater into the overlying aquifers can not be conclusively demonstrated.

\subsubsection{Recommendations}

As it is not possible to collect the required data from existing wells, it is recommended that three to four new wells be installed and additional geophysical data collected. The proposed logging suite for the new wells will provide the data needed to augment available information from the site and support an evaluation of the Middle Confining Unit's ability to prevent upward migration of contaminants. Specifically, these data can then be used to determine the lateral continuity (gamma-ray spontaneous potential, and borehole sonic logs) and effective confining thickness of the Middle Confining Unit (compensated density/neutron logs and the bore-hole compensated sonic log). Deep resistivity logs (lateral $\operatorname{logs}$ ), near well resistivity (micro-resistivity logs), bore-hole temperature logs, resistivity of the mud filtrate measurements, and spontaneous potential logs can be used to determine the Middle Confining Unit's pore water electrical conductivity. These data can be compared with injected water electrical conductivity to determine if the migration through the Middle Confining Unit has occurred at the well location. In addition, the resistivity logs can be used for quantitatively identifying high permeable zones, the presence of fracture zones, and together with whole core analysis measurements for establishing potential resistivity permeability relationships.

Collection of whole core samples from the Middle Confining Unit for laboratory measurement of porosity and permeability will provide a means for both calibrating log derived porosities and establishing the relationship between log derived porosity measurements from the density/neutron and bore-hole sonic logs (resistivitv data can potentially be used in the same manner) with the core derived permeability laboratory measurements. Establishing this relationship will allow for a qualitative estimate to be made of permeabilities of the Middle Confining Unit in the absence of laboratory measurements. This would then be used to calculate the effective confining layer thickness using an appropriate permeability value. There is also the potential for using these relationships to qualitatively estimating permeability at other well locations that have appropriate data sets (porosity/resistivity logs). Analysis of the mineralogical properties of the core will allow for an analysis of the compatibility of the waste and the injected wastewater to be made.

Logging redundancy is provided for porosity measurements through logging the new wells with the density, neutron, and borehole sonic tools. This redundancy allows for higher confidence in calculated porosity values for the Middle Confining Unit and therefore is important for determining the porosity permeability relationship. Another reason for running each of these logs is that wellbore conditions and lithology have impacts on each of these logs that can potentially affect the quality and appropriateness of the data for porosity determination. Additionally, the sonic log provides additional information for determining lateral continuity of specific lithologic units. 
The recommended geophysical logging suite and analysis for the new wells is outlined below.

- $\quad$ Gamma-ray logs

- $\quad$ Compensated density/neutron logs

- $\quad$ Lateral logs (deep resistivity)

- $\quad$ Micro-resistivity logs (near borehole resistivity)

- $\quad$ Borehole temperature $\log s$

- $\quad$ Spontaneous potential logs

The following laboratory analyses are also recommended.

- Whole-core analysis of core samples (porosity, permeability, and mineralogy)

- $\quad$ Electrical conductivity of the mud filtrate (or water if no drilling mud is used)

- $\quad$ Electrical conductivity of treated wastewater

The following data analysis and interpretation should be performed on these data sets.

- Porosity determination

- $\quad$ Formation fluid conductivity

- $\quad$ Core permeability / density cross plots

- $\quad$ Net thickness of effective confining zone 


\section{EVALUATION OF HYDROGEOLOGIC DATA}

The hydraulic head relationships between units, hydrostratigraphy, and hydraulic conductivity of various units were reviewed. Conclusions and recommendations are provided in Section 6.3.

\subsection{Hydraulic Head}

Hydraulic head is a measure of the mechanical energy (pressure, elevation, and velocity) at a point in a flow system. Differences in hydraulic head cause fluid flow. Thus hydraulic head gradients (i.e., the difference in hydraulic head per unit length along a flow path) can be used to infer the direction of groundwater flow and, in conjunction with hydraulic conductivity, the groundwater flux. In addition, comparison of the hydraulic heads in different units can be used to infer the degree to which the units are hydraulically connected or isolated.

The hydraulic head data available for review were presented in Draft Supplemental to Report No. B - Geochemical Study Report - Potentiometric Maps of the Floridan Aquifer and the Boulder Zone for South District Wastewater Treatment Plant, Dade County, Florida (Rust 1998a).

The salinity (and hence the density) of ground water varies with depth at the site. Different wells at the SDWTP contain water of different salinity and density. If the hydraulic head is determined by measuring pressure at the well head and calculating the additional head due to the weight of the fluid column between the well head and the open interval of the well, errors will be introduced unless the fluid density is taken into account. For situations in which fluid density is variable, the hydraulic head typically is reported as equivalent freshwater head (i.e., the elevation to which fresh water would rise in a well). From the information presented, it cannot be determined whether the effects of variations in fluid density have been considered.

The data presented included hydrographs for each monitoring well and injection well. Each hydrograph covered the same approximate 10,000-minute (about 1-week) period. In many cases, the hydrographs showed step changes in the hydraulic head. The cause of these step changes was not explained by Rust (1998a). Several causes of these step changes can be hypothesized:

- $\quad$ The operating state (shut in or discharging at the surface) of either the well being monitored or a nearby well was changed during the data collection period

- The depth of the pressure transducer used for measuring head was changed

- The data logger operating parameters were changed during the data collection period

- $\quad$ An equipment malfunction occurred.

Because these relatively large variations have not been satisfactorily explained, the validity of these hydrographs is suspect. Nevertheless, an attempt was made to use data from the hydrographs. It was assumed that the data presented are correct and are representative of hydraulic conditions in the zones monitored. It is also assumed that the step changes in head are caused by changes in well operation.

The horizontal and vertical distribution of hydraulic head at various depths was determined by comparing head values measured at essentially the same time. The head varied throughout the approximate 10,000-minute monitoring period, and in some cases (e.g., Well FA-10 L) the head appeared to be rebounding throughout the monitoring period. To compare values that were as close as possible to steady state conditions, values measured late in the monitoring period were used in this analysis. The data 
point closest to an elapsed time of 9,000 minutes on each hydrograph was identified and its value was determined by scaling off of the hydrograph.

Table 1 shows the measured head values, which are grouped according to depth. Data from wells at different depths but in close proximity horizontally are shown on the same line.

Contour plots of the measured head at the 1,000,1,500,1,800-ft depth horizons in the Upper Floridan Aquifer and in the Boulder Zone (the zone of injection) are provided in Figures 2 through 5 , respectively.

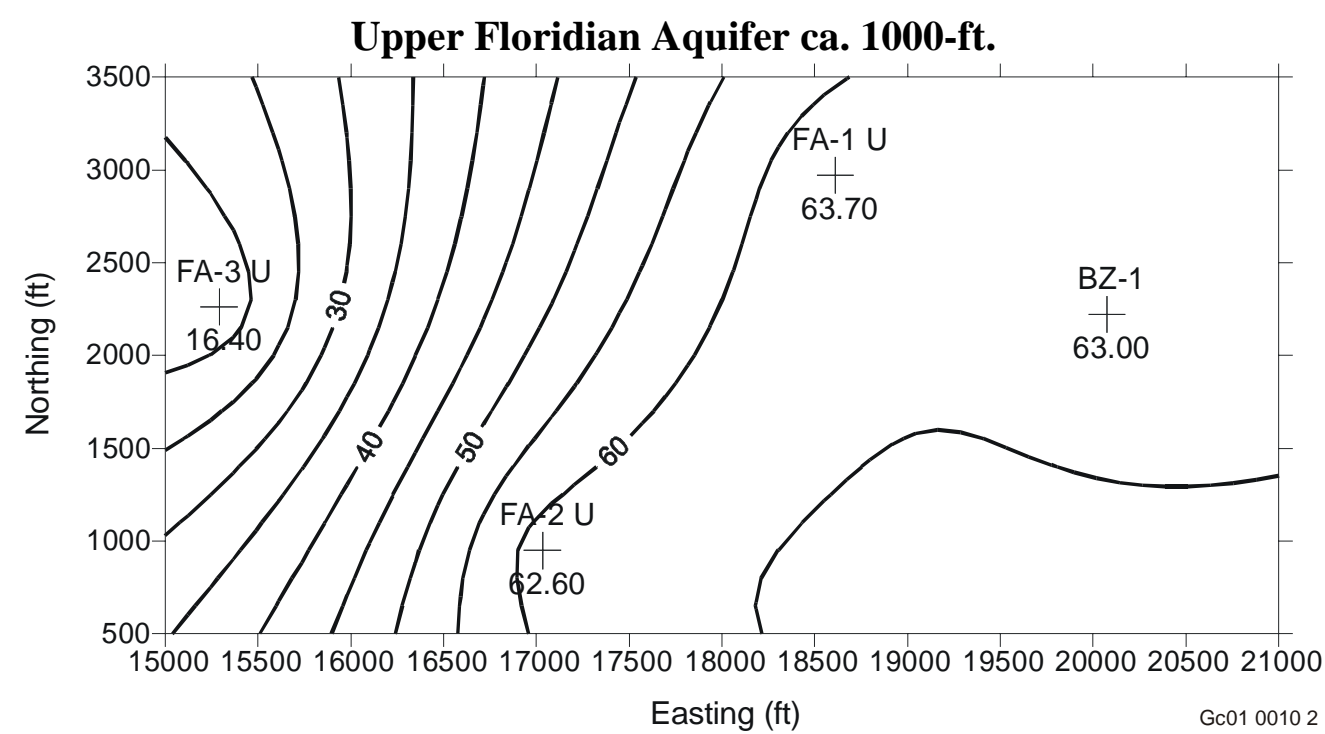

Figure 2. Hydraulic head (ft) at approximately 1,000-ft bls.

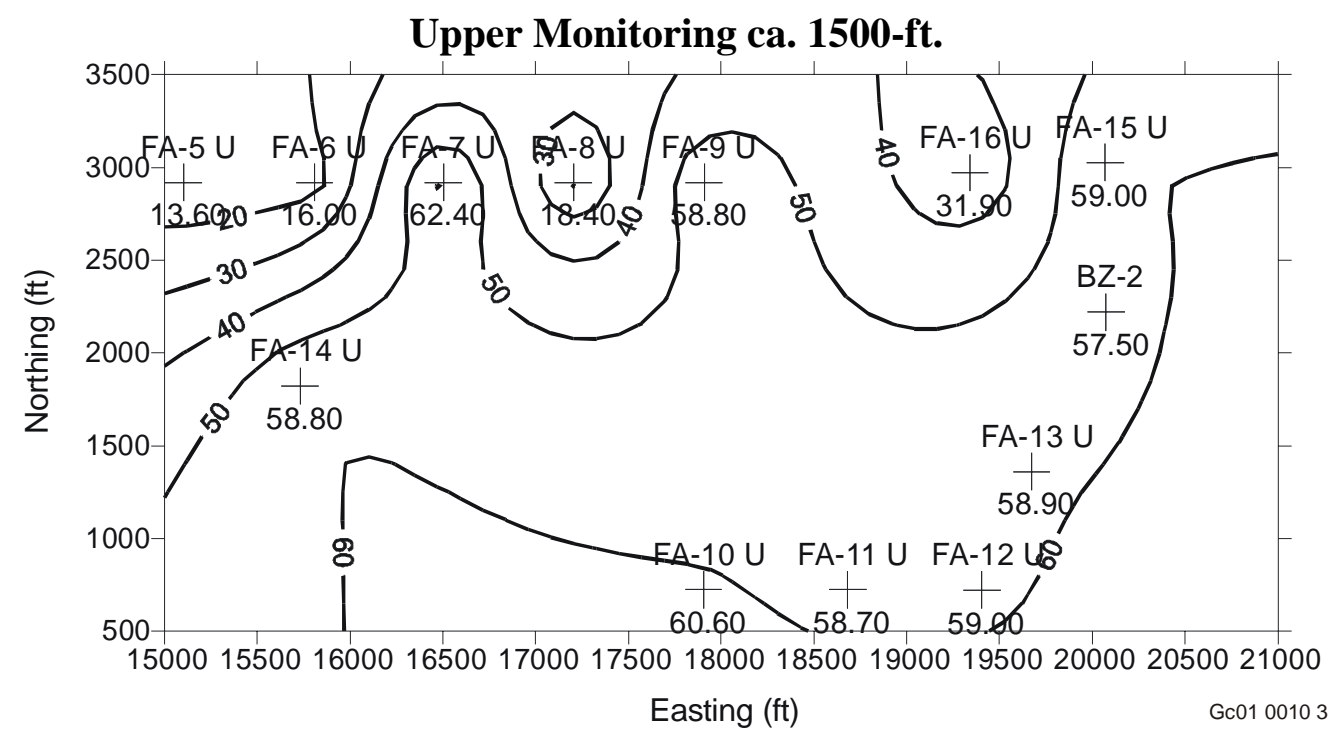

Figure 3. Hydraulic head (ft) at approximately 1,500-ft bls. 
Table 1. Hydraulic head at approximately 9,000 minutes (data from Rust 1998a).

\begin{tabular}{|c|c|c|c|c|c|c|c|c|c|c|c|c|c|c|c|c|c|c|c|}
\hline Well & $\begin{array}{c}\text { Top } \\
\text { (ft bls) }\end{array}$ & $\begin{array}{l}\text { Bottom } \\
\text { (ft bls) }\end{array}$ & $\begin{array}{l}\text { Midpoint } \\
\text { (ft bls) }\end{array}$ & $\begin{array}{c}\text { Head } \\
(\mathrm{ft})\end{array}$ & Well & $\begin{array}{c}\text { Top } \\
\text { (ft bls) }\end{array}$ & $\begin{array}{l}\text { Bottom } \\
\text { (ft bls) }\end{array}$ & $\begin{array}{l}\text { Midpoint } \\
\text { (ft bls) }\end{array}$ & $\begin{array}{l}\text { Head } \\
(\mathrm{ft})\end{array}$ & Well & $\begin{array}{c}\text { Top } \\
\text { (ft bls) }\end{array}$ & $\begin{array}{l}\text { Bottom } \\
\text { (ft bls) }\end{array}$ & $\begin{array}{l}\text { Midpoint } \\
(\mathrm{ft} \text { bls })\end{array}$ & $\begin{array}{c}\text { Head } \\
(\mathrm{ft})\end{array}$ & Well & $\begin{array}{c}\text { Top } \\
\text { (ft bls) }\end{array}$ & \multicolumn{2}{|c|}{$\begin{array}{l}\text { Bottom Midpoint } \\
\text { (ft bls) (ft bls) }\end{array}$} & $\begin{array}{c}\text { Head } \\
(\mathrm{ft})\end{array}$ \\
\hline \multicolumn{5}{|c|}{ UFA 1,000-ft } & \multicolumn{5}{|c|}{ Upper Monitoring 1,500-ft } & \multicolumn{5}{|c|}{ Lower Monitoring 1,800-ft } & \multicolumn{5}{|c|}{ Injection Wells } \\
\hline & & & & & FA-10 U & 1490 & 1592 & 1541 & 60.6 & FA-10 L & 1790 & 1890 & 1840 & 38.6 & $\mathrm{I}-1$ & 2628 & 3110 & 2869 & 96.0 \\
\hline & & & & & FA-11 U & 1490 & 1588 & 1539 & 58.7 & FA-11 L & 1790 & 1890 & 1840 & 61.0 & $\mathrm{I}-2$ & 2628 & 2824 & 2726 & 96.0 \\
\hline & & & & & FA-12 U & 1495 & 1597 & 1546 & 59.0 & FA-12 L & 1790 & 1890 & 1840 & 16.0 & $\mathrm{I}-3$ & 2629 & 3123 & 2876 & 96.0 \\
\hline & & & & & FA-13 U & 1480 & 1585 & 1533 & 58.9 & FA-13 L & 1740 & 1845 & 1793 & 34.9 & $\mathrm{I}-4$ & 2664 & 3133 & 2899 & 96.0 \\
\hline & & & & & & & & & & & & & & & $\mathrm{I}-5$ & 2746 & 3193 & 2970 & 97.3 \\
\hline BZ-1 & 1005 & 1037 & 1021 & 63.0 & BZ-2 & 1577 & 1664 & 1621 & 57.5 & & & & & & & & & & \\
\hline & & & & & FA-15 U & 1490 & 1575 & 1533 & 59.0 & FA-15 L & 1790 & 1890 & 1840 & 31.7 & I-6 & 2740 & 3112 & 2926 & 96.0 \\
\hline & & & & & FA-16 U & 1490 & 1590 & 1540 & 31.9 & FA-16 L & 1790 & 1890 & 1840 & 34.5 & $\mathrm{I}-7$ & 2628 & 3119 & 2874 & 96.0 \\
\hline FA-1 U & 980 & 1090 & 1035 & 63.7 & & & & & & FA-1 L & 1840 & 1927 & 1884 & 32.7 & $\mathrm{I}-8$ & 2420 & 3112 & 2766 & 97.3 \\
\hline FA-2 U & 980 & 1020 & 1000 & 62.6 & & & & & & FA-2 L & 1645 & 1672 & 1659 & 55.4 & I-9 & 2418 & 3111 & 2765 & 96.0 \\
\hline & & & & & & & & & & FA-4 L & 1702 & 1840 & 1771 & 34.9 & $\mathrm{I}-10$ & 2425 & 3028 & 2727 & 96.0 \\
\hline & & & & & FA-14 U & 1490 & 1575 & 1533 & 58.8 & & & & & & $\mathrm{I}-11$ & 2428 & 3015 & 2722 & 96.0 \\
\hline FA-3 U & 981 & 1050 & 1016 & 16.4 & & & & & & FA-3 L & 1771 & 1892 & 1832 & 15.6 & $\mathrm{I}-12$ & 2392 & 3060 & 2726 & 96.0 \\
\hline & & & & & FA-5 U & 1490 & 1588 & 1539 & 13.6 & FA-5 L & 1790 & 1890 & 1840 & 16.5 & $\mathrm{I}-13$ & 2400 & 3060 & 2730 & 96.0 \\
\hline & & & & & FA-6 U & 1490 & 1584 & 1537 & 16.0 & FA-6 L & 1790 & 1890 & 1840 & 33.1 & $\mathrm{I}-14$ & 2403 & 3060 & 2732 & 82.4 \\
\hline & & & & & FA-7 U & 1488 & 1580 & 1534 & 62.4 & FA-7 L & 1805 & 1875 & 1840 & 49.5 & $\mathrm{I}-15$ & 2410 & 3060 & 2735 & 84.1 \\
\hline & & & & & FA-8 U & 1490 & 1575 & 1533 & 18.4 & FA-8 L & 1790 & 1890 & 1840 & 31.4 & $\mathrm{I}-16$ & 2530.6 & 3055 & 2793 & 84.3 \\
\hline & & & & & FA-9 U & 1490 & 1587 & 1539 & 58.8 & FA-9 L & 1780 & 1880 & 1830 & 33.0 & $\mathrm{I}-17$ & 2530.6 & 3070 & 2800 & 74.2 \\
\hline
\end{tabular}




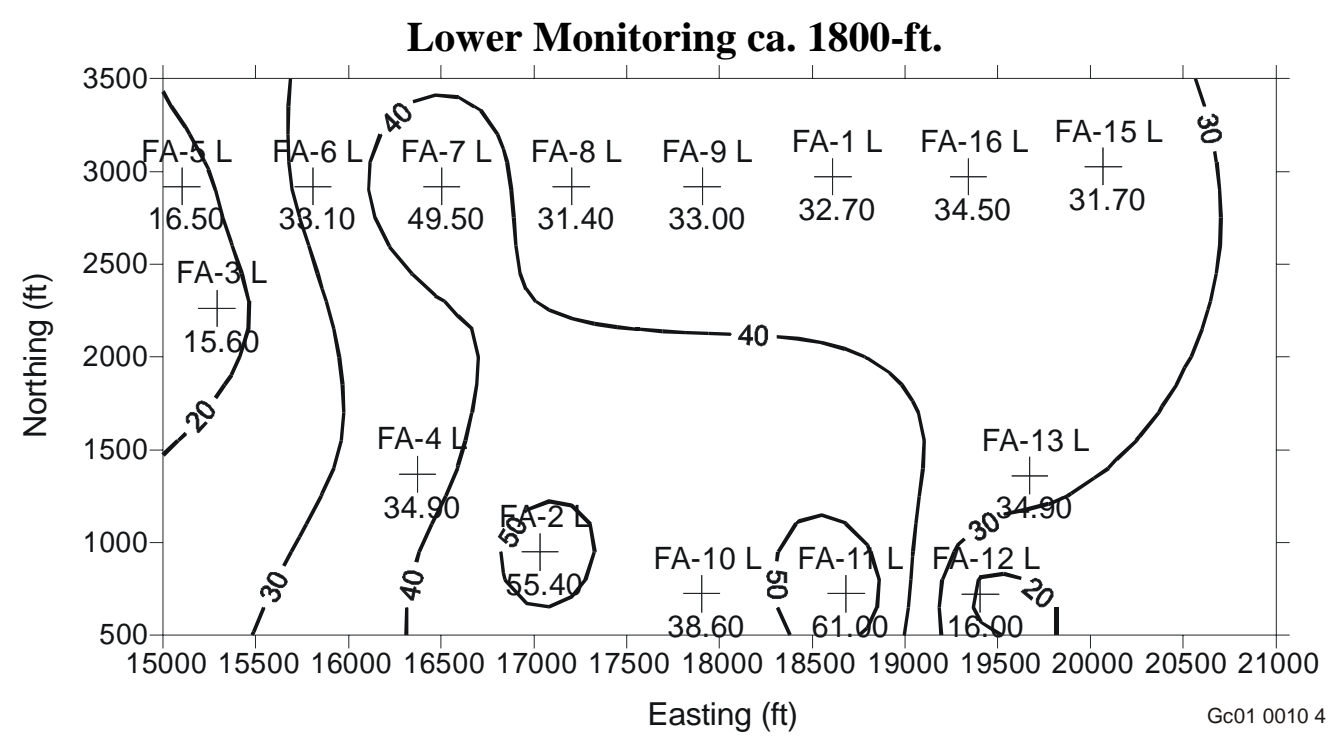

Figure 4. Hydraulic head (ft) at approximately 1,800-ft bls.

\section{Injection Wells}

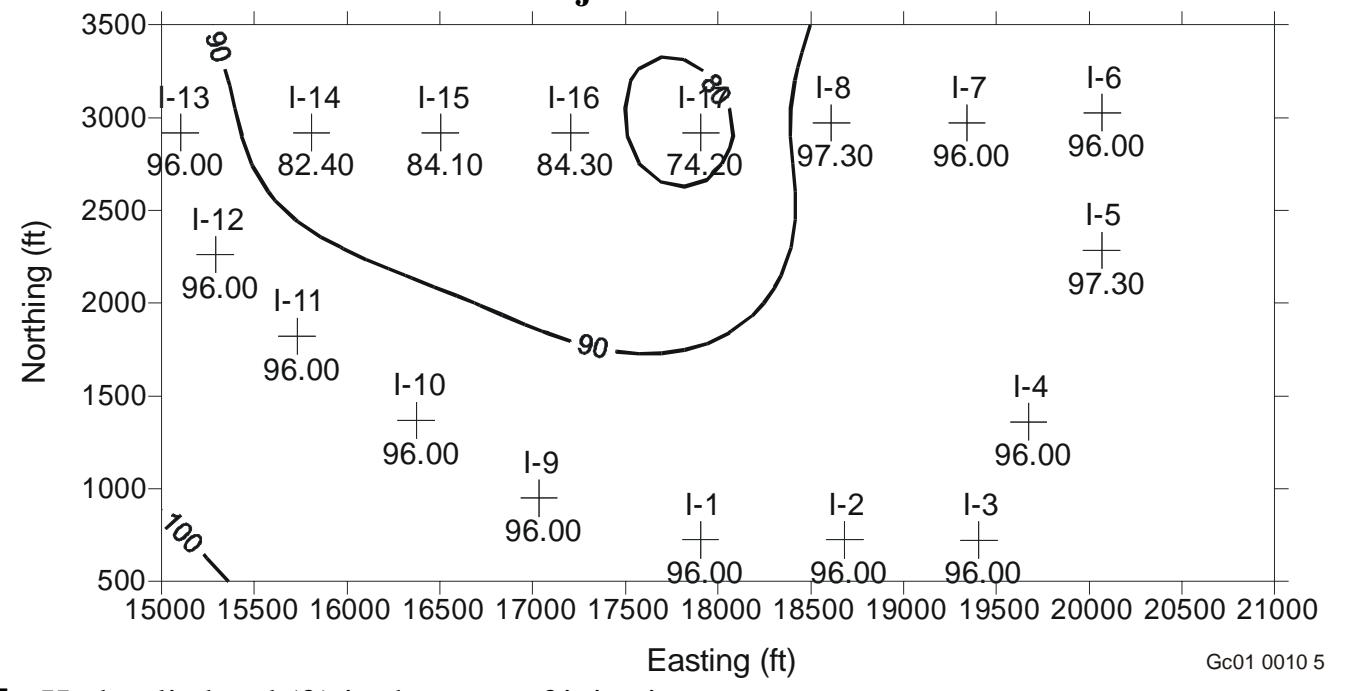

Figure 5. Hydraulic head (ft) in the zone of injection.

In the 1,000-ft zone, heads are approximately constant at $63-\mathrm{ft}$ in the eastern portion of the domain and decline to about 16-ft in the western portion. The hydrograph for Well FA-3U does not contain a step change that would suggest that the well was being purged (i.e., allowed to flow). Nevertheless, it was assumed that it was being purged, and thus the measured head does not represent a static value for the aquifer. Similar effects can be seen in the plot for the 1,500-ft zone, in which several wells along the north line appear to have been purging. In the $1,800-\mathrm{ft}$ zone, head values fall into three general clusters: approximately $16-\mathrm{ft}$, approximately $33-\mathrm{ft}$, and approximately 50 to $60-\mathrm{ft}$. It is not known whether the wells with head values of approximately $33-\mathrm{ft}$ were being purged. If they were being purged, then the head value of 61-ft measured in FA-11 L would represent an equilibrium head value for this zone. In contrast, if they were not being purged, then the equilibrium head in this zone is probably about 33 -ft and the higher head values represent anomalies that could either be measurement error or indicate that the well is hydraulically connected to deeper zones where the head is higher. Unfortunately, the correct alternative cannot be determined from the information provided. 
The head contour plot for the zone of injection shows that the head in the injection wells is clustered either at $96-\mathrm{ft}$ or approximately $83-\mathrm{ft}$. It is assumed that the wells that have heads of $96-\mathrm{ft}$ were being used for injecting wastewater, while the wells with head of approximately $83-\mathrm{ft}$ were shut in. Again, information needed to evaluate this assumption was not provided. If this assumption is correct, it suggests that injection at the flow rates used increases the head by approximately $13-\mathrm{ft}$, and thus head changes can be imposed in the aquifer by changing the pattern of injection wells used.

Two very important caveats apply to this analysis:

1. If the reported heads are based on pressure measured at the well head and if only some of the wells were being actively used for injecting wastewater, the frictional losses of energy in the well casing and in the formation immediately adjacent to the well bore would cause the measured head to be greater in wells used for injection than in shut-in wells and to be greater than the head in the formation adjacent to the well. Hence, the head increase in the formation due to injection would be less than 13 feet.

2. Corrections for the density of fluids in the well casing must be made if the salinity, and hence density, of fluids varies between wells. For example, the fluid in operating injection wells would be low-salinity, low-density water. In contrast, wells that have either not been used for injection or that have been purged since they were used for injection would probably contain brine from the formation. The density of the fluid in the well is important in determining hydraulic head from pressure measured at the wellhead. Hydrostatic pressure varies with depth according to $\Delta P=\rho g \Delta Z$, where $P$ is pressure, $\rho$ is the density of the fluid, $g$ is gravity, and $\mathrm{Z}$ is elevation (or depth). Pressure varies more rapidly with depth for a fluid with higher density (e.g. brine) than with a less dense fluid (e.g. fresh water). Thus, for a given head at the bottom of a well, the pressure at the wellhead would be greater if the well were filled with fresh water than if it were filled with brine. This would lead to an error in the value of hydraulic head calculated as the sum of pressure head and elevation head at the wellhead, unless fluid density is considered. For a 2,500 foot deep well (comparable to the injection wells at SDWTP), the difference in wellhead pressure if the well were filled with fresh water (specific gravity 1.00) or filled with brine (specific gravity 1.03 ) would be 32.5 pounds per square inch, which corresponds to a difference in calculated hydraulic head of 75 feet. Thus, the observed difference in head between injection wells (approximately 13 feet) could easily be attributed to differences in the density of fluid in different wells.

The hydraulic head data sets provided are difficult to interpret because some wells in each interval were probably being purged during the data collection period and because purging of some wells either began or stopped during the data collection period. A better approach for providing data that could be used for determining the lateral and vertical distribution of hydraulic head beneath the site would be to shut in all monitoring wells and to monitor head until recovery to static conditions had occurred. This approach would remove the perturbations to the system caused by drawdown cones created by well purging. If head were monitored until steady-state conditions were reached, then anomalous values could be identified and possibly correlated with hydraulic connections to other hydrostratigraphic units.

Regardless of the effects of the local head perturbations, the hydraulic head in the zone of injection (Figure 5) is higher than that in the Upper Floridan Aquifer (Figures 2 through 4), and therefore groundwater tends to flow upward from the zone of injection, through the Middle Confining Unit, and into the overlying Upper Floridan Aquifer. The amount of water that moves upward through the Middle Confining Unit and the rate at which it moves depends on the hydraulic conductivity of the Middle Confining Unit, which is discussed in the following section. 


\subsection{Hydrostratigraphy and Hydraulic Conductivity}

The Upper Confining Unit and the Middle Confining Unit have been identified as aquitards by investigators working on a regional scale. These hydrostratigraphic units have been identified at the site by correlating regional and local stratigraphy. For example, stratigraphic sections for the site are presented in Rust (1998a).

The Middle Confining Unit is being relied upon as a barrier to the upward migration of wastewater from the Boulder Zone into the overlying Upper Floridan Aquifer. In order for the Middle Confining Unit to function as a contaminant transport barrier, it must be composed of material with low vertical hydraulic conductivity and there can be no high hydraulic conductivity pathways that penetrate its vertical thickness.

The hydraulic properties of the Middle Confining Unit at the site can be determined by hydraulic tests such as slug tests or pumping tests. A very limited hydraulic test data set was provided for review. This data set includes a journal article that describes hydraulic testing of test Well I-5 performed in 1977 (Singh, Garcia-Bengochea, and Sproul 1980), and a table entitled Packer Test Results (MDWSD 1994) that includes calculated transmissivity and hydraulic conductivity values for selected intervals in Wells I-13 through I-16.

Singh, Garcia-Bengochea, and Sproul (1980) reported the results of hydraulic tests in terms of transmissivity (T), which is the product of hydraulic conductivity (K) and thickness (b), while the Packer Test Results table lists hydraulic conductivity. Transmissivity values from packer tests performed above the Boulder Zone reported by Singh, Garcia-Bengochea, and Sproul (1980) were converted to hydraulic conductivity by dividing the reported transmissivity by the length of the test interval. In addition to the packer tests, Singh, Garcia-Bengochea, and Sproul (1980) reported that one pumping test was performed in the Boulder Zone. The reported transmissivity value was converted to hydraulic conductivity by dividing by the length of the open-hole completion zone (2,746 to 3,193-ft bls).

The MDWSD (1994) table contains from one to three hydraulic conductivity values for each interval tested. Presumably, replicate tests were performed in some, but not all, intervals. The arithmetic average of the values for each interval was computed and used in subsequent comparisons.

Tables 2 and 3 show the data extracted from Singh, Garcia-Bengochea, and Sproul (1980) and from MDWSD (1994), and the calculated hydraulic conductivity values.

A plot of these measured values as a function of depth below land surface is provided in Figure 6 . In addition, contacts between hydrostratigraphic units are shown. The contacts between the MCU and the Upper and Lower Floridan Aquifer were taken from Draft Supplemental to Report No. B-Geochemical Study Report Potentiometric Maps of the Floridan Aquifer and the Boulder Zone for South District Wastewater Treatment Plant, Dade County, Florida (Rust 1998a, Figure 4-5). The top of the Boulder Zone was inferred to be the top of the open-hole completion portion of the well (I-5) tested by Singh, Garcia-Bengochea, and Sproul (1980).

The typical range of permeability and hydraulic conductivity values observed for various consolidated and unconsolidated materials and values observed at the SDWTP are illustrated in Figure 7. This figure provides a basis for comparing the range of values measured at the site to typical values for limestone and other materials. 
Table 2. Hydraulic test data from Singh, Garcia-Bengochea, and Sproul (1980).

\begin{tabular}{ccccccc}
\hline $\begin{array}{c}\text { Test } \\
\text { No. }\end{array}$ & $\begin{array}{c}\text { Interval } \\
\text { Top } \\
(\mathrm{ft})\end{array}$ & $\begin{array}{c}\text { Interval } \\
\text { Bottom } \\
(\mathrm{ft})\end{array}$ & $\begin{array}{c}\text { Interval } \\
\text { Length } \\
(\mathrm{ft})\end{array}$ & $\begin{array}{c}\text { Average } \\
\text { Depth } \\
(\mathrm{ft})\end{array}$ & $\begin{array}{c}\mathrm{T} \\
\left(\mathrm{gpd}^{\left.-\mathrm{ft}^{-1}\right)}\right.\end{array}$ & $\begin{array}{c}\mathrm{K} \\
\left(\mathrm{cm} \mathrm{s}^{-1}\right)\end{array}$ \\
\hline 5 & 1968 & 1998 & 30 & 1983 & 177 & $2.8 \mathrm{E}-04$ \\
3 & 2367 & 2397 & 30 & 2382 & 140 & $2.2 \mathrm{E}-04$ \\
6 & 2008 & 2759 & 751 & 2383.5 & 653 & $4.1 \mathrm{E}-05$ \\
7 & 2543 & 2573 & 30 & 2558 & 143 & $2.2 \mathrm{E}-04$ \\
4 & 2407 & 2759 & 352 & 2583 & 350 & $4.7 \mathrm{E}-05$ \\
10 & 2652 & 2682 & 30 & 2667 & 96 & $1.5 \mathrm{E}-04$ \\
8 & 2583 & 2759 & 176 & 2671 & 326 & $8.7 \mathrm{E}-05$ \\
2 & 2697 & 2727 & 30 & 2712 & 92 & $1.4 \mathrm{E}-04$ \\
9 & 2692 & 2759 & 67 & 2725.5 & 264 & $1.9 \mathrm{E}-04$ \\
1 & 2737 & 2759 & 22 & 2748 & 63 & $1.4 \mathrm{E}-04$ \\
Pumping & 2746 & 3193 & 447 & 2970 & $1.4 \mathrm{E}+07$ & $1.5 \mathrm{E}+00$ \\
Test & & & & & & \\
\hline
\end{tabular}

Table 3. Hydraulic test data from MDWSD (1994).

\begin{tabular}{|c|c|c|c|c|c|c|c|}
\hline Well & $\begin{array}{l}\text { Interval } \\
\text { Top } \\
\text { (ft) }\end{array}$ & $\begin{array}{l}\text { Interval } \\
\text { Bottom } \\
\text { (ft) }\end{array}$ & $\begin{array}{l}\text { Average } \\
\text { Depth } \\
\text { (ft) }\end{array}$ & $\left(\mathrm{cm} \mathrm{s}^{-1}\right)$ & $\begin{array}{l}\text { sured Hydr } \\
\text { Conductivit } \\
\qquad\left(\mathrm{cm} \mathrm{s}^{-1}\right)\end{array}$ & $\left(\mathrm{cm} \mathrm{s}^{-1}\right)$ & $\begin{array}{l}\text { Mean K } \\
\left(\mathrm{cm} \mathrm{s}^{-1}\right)\end{array}$ \\
\hline $\mathrm{I}-13$ & 1500 & 1560 & 1530 & 0.0003 & 0.0006 & 0.00016 & $3.5 \mathrm{E}-04$ \\
\hline $\mathrm{I}-14$ & 1510 & 1540 & 1525 & 0.032 & 0.033 & - & 3.3E-02 \\
\hline $\mathrm{I}-15$ & 1530 & 1560 & 1545 & 0.043 & - & - & 4.3E-02 \\
\hline I-16 & 1560 & 1590 & 1575 & 0.0052 & 0.0026 & - & $3.9 \mathrm{E}-03$ \\
\hline $\mathrm{I}-13$ & 1750 & 1810 & 1780 & 0.0002 & 0.0004 & 0.00016 & $2.5 \mathrm{E}-04$ \\
\hline $\mathrm{I}-14$ & 1980 & 2010 & 1995 & 0.01 & 0.0037 & 0.0167 & $1.0 \mathrm{E}-02$ \\
\hline $\mathrm{I}-15$ & 2040 & 2070 & 2055 & 0.00017 & 0.000029 & 0.00014 & $1.1 \mathrm{E}-04$ \\
\hline $\mathrm{I}-13$ & 2090 & 2120 & 2105 & 0.00061 & 0.00048 & 0.00076 & $6.2 \mathrm{E}-04$ \\
\hline $\mathrm{I}-15$ & 2190 & 2220 & 2205 & 0.00012 & 0.000011 & 0.0076 & $2.6 \mathrm{E}-03$ \\
\hline $\mathrm{I}-14$ & 2240 & 2270 & 2255 & 0.00305 & 0.007 & 0.003 & 4.4E-03 \\
\hline
\end{tabular}




\section{Hydraulic Conductivity from Packer Tests}

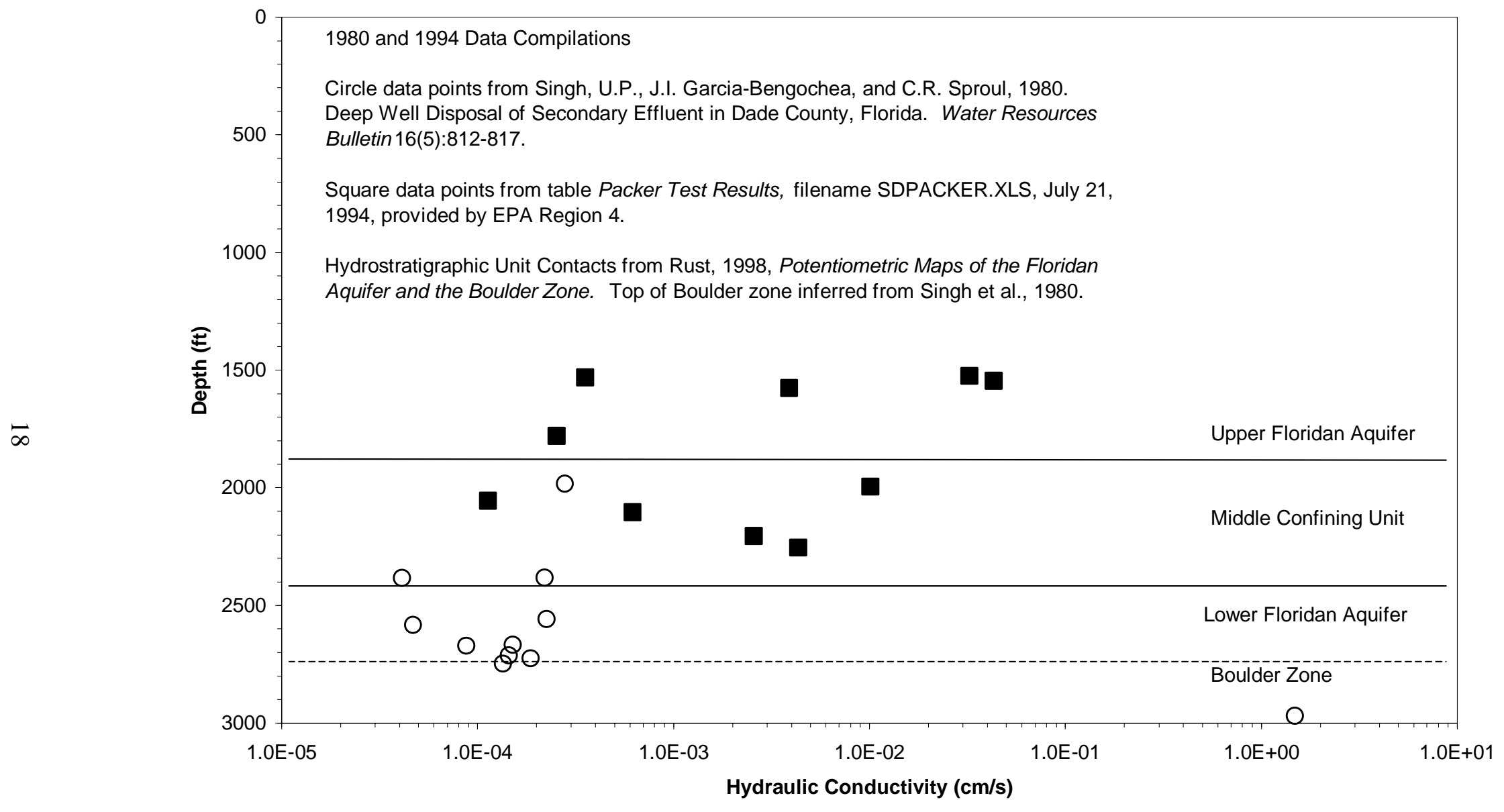

Figure 6. Hydraulic test data from Singh, Garcia-Bengochea, and Sproul (1980) and MDWSD (1994). 


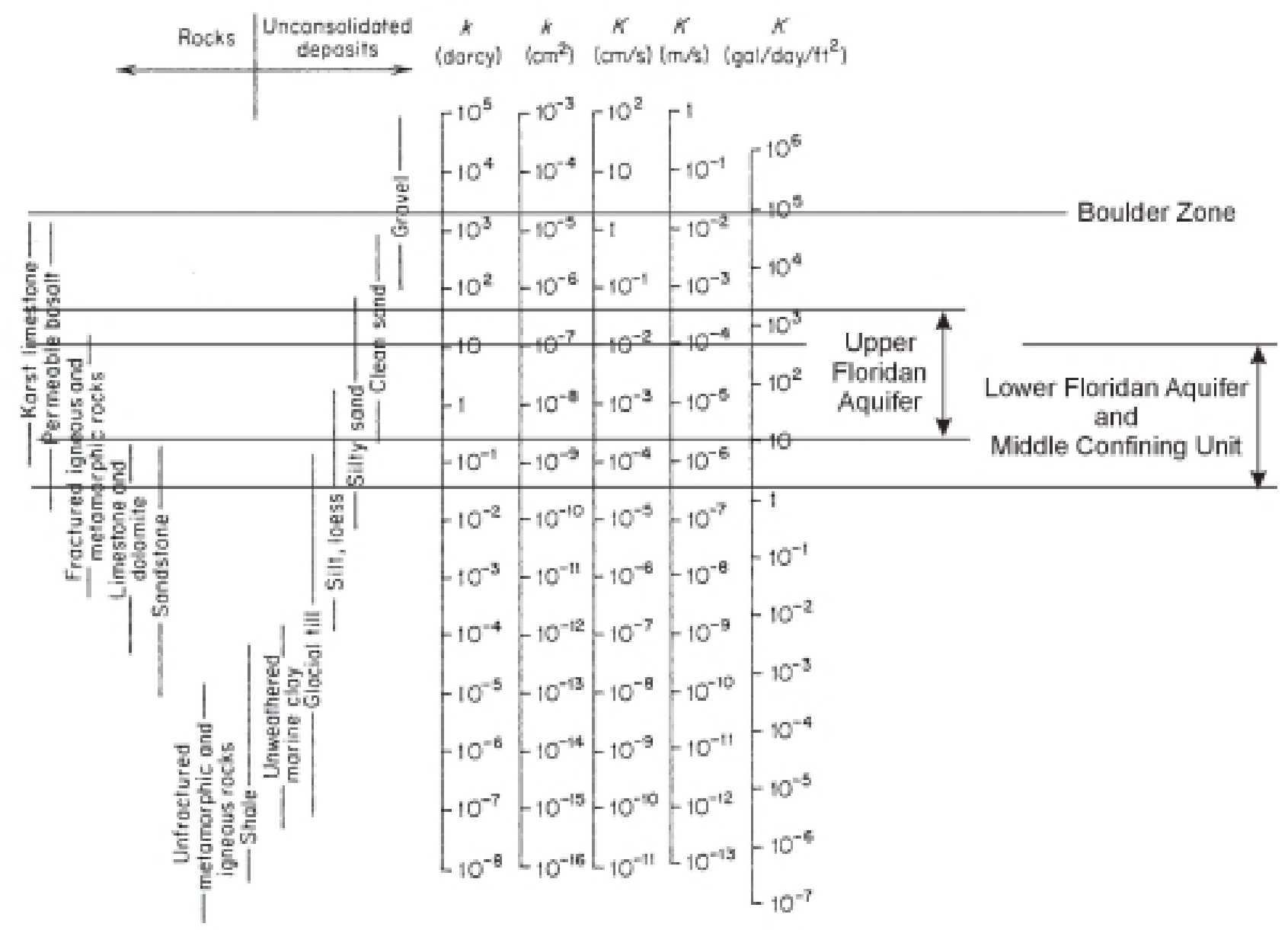

Figure 7. Typical range of hydraulic properties of geologic materials (Freeze and Cherry 1979) and range of observed values at the SDWTP 
Several observations can be made about the hydraulic conductivity values measured at the site:

- $\quad$ Boulder Zone

The single measured hydraulic conductivity value for the Boulder Zone, $1.5 \times 10^{0} \mathrm{~cm} \mathrm{~s}^{-1}$, is approximately two orders of magnitude larger than measured values in the overlying portion of the Lower Floridan Aquifer and the Middle Confining Unit. The measured hydraulic conductivity of the Boulder Zone is quite high comparable to the hydraulic conductivity of coarse sand or gravel and falls in the range for karst limestone. It is approximately three orders of magnitude greater than the upper end of the range for non-karst limestone (Figure 7). This interpretation must be qualified because only one measured value for the Boulder Zone was available. The degree that this value is representative of the Boulder Zone cannot be assessed from such limited data set.

- $\quad$ Upper Portion of the Lower Floridan Aquifer and the Middle Confining Unit

The majority of the hydraulic conductivity values measured in the upper portion of the Lower Floridan Aquifer and the Middle Confining Unit range from approximately $1 \times 10^{-4}$ to $1 \times 10^{-2} \mathrm{~cm} \mathrm{~s}^{-1}$. (The three smallest measured values in the Lower Floridan Aquifer, which are slightly less than $1 \times 10^{-4} \mathrm{~cm} \mathrm{~s}^{-1}$, were measured in very long test intervals-176 to 751 $\mathrm{ft}$ - while the remainder of the values were measured in test intervals of 60 -ft or less. Because of the substantial differences in the length of the test interval, the three lowest values are not directly comparable to the remainder of the data set.) These hydraulic conductivity values are comparable to values for silty sand to clean sand (Figure 7). The smallest values are at the upper end of the range for non-karst limestone, and the entire range of values (excluding the three values measured in very long test intervals) falls within the range of karst limestone and for silty to clean sand as shown in Figure 7.

The hydraulic conductivity values measured in the Lower Floridan Aquifer are generally lower than the values measured in the Middle Confining Unit. This suggests that the identification of hydrostratigraphic units at the site was not made on the basis of hydraulic conductivity values measured at the site. (In general, the hydrostratigraphic units with higher hydraulic conductivity are called 'aquifers', and the units with lower hydraulic conductivity are called 'confining units'.)

- Upper Floridan Aquifer

Three of the five hydraulic conductivity values measured in the Upper Floridan Aquifer are in the range of $1 \times 10^{-4}$ to $1 \times 10^{-2} \mathrm{~cm} \mathrm{~s}^{-1}$, and the remaining two values are in the range $1 \times 10^{-2}$ to $1 \times 10^{-1} \mathrm{~cm} \mathrm{~s}^{-1}$. The three lower values are in the range measured for the Middle Confining Unit and correspond to the range reported for silty to clean sand and karst limestone (Figure 7). The two higher values fall in the range reported for karst limestone and clean sand.

Based on the hydraulic conductivity values measured at the site, it appears that the Boulder Zone has substantially higher hydraulic conductivity than the overlying hydrostratigraphic units (assuming that the single measured value is representative of the Boulder Zone). It is also clear that neither the upper portion of the Lower Floridan Aquifer nor the Middle Confining Unit is composed of low hydraulic conductivity materials. These units have hydraulic conductivity values that fall in the range of karst limestone or silty to clean sand. Although these units have lower conductivity than that of the Boulder Zone and possibly other regional aquifers and, therefore, may act as aquitards in terms of regional flow 
systems, it is difficult to believe that materials with hydraulic conductivity of $10^{-4} \mathrm{~cm} \mathrm{~s}^{-1}$ or greater would be an effective barrier to the migration of fluids out of the zone of injection.

This interpretation was made based on the data available, but must be qualified because the measured hydraulic conductivity values may be higher than the values of hydraulic conductivity that control vertical flow in this system. There are three sources of this potential bias. (1) In a horizontally layered system in which the layers have different hydraulic conductivity values, for the ensemble of layers the horizontal hydraulic conductivity $\left(\mathrm{K}_{\mathrm{H}}\right)$ is larger than the vertical hydraulic conductivity $\left(\mathrm{K}_{\mathrm{V}}\right)$ (Figure 8). This occurs because horizontal flow is controlled primarily by the high conductivity layers and is relatively insensitive to the low conductivity layers, while vertical flow is controlled primarily by the low conductivity layers and is insensitive to the high conductivity layers. Therefore, in a horizontally layered system $\mathrm{K}_{\mathrm{V}}$ is less than $\mathrm{K}_{\mathrm{H}}$. (2) Hydraulic tests conducted in vertical wells or boreholes measure $\mathrm{K}_{\mathrm{H}}$, not $\mathrm{K}_{\mathrm{V}}$, and therefore $\mathrm{K}_{\mathrm{V}}$ is less than $\mathrm{K}_{\text {Measured }}$ in a horizontally layered system. (3) The response of a hydraulic test performed in a well or borehole is dominated by the layers that have higher hydraulic conductivity, and therefore $\mathrm{K}_{\text {Measured }}$ is generally greater than the hydraulic conductivity of the lower conductivity layers in the test interval. The potential bias toward high values in the hydraulic conductivity data set would cause the estimates of vertical flux - which is controlled by the lower conductivity layers in the system - to be too large, and estimates of travel time to be too small. Although we recognize that the hydraulic conductivity data set may be biased high relative to $\mathrm{K}_{\mathrm{V}}$, the vertical flux and travel time are estimated in the following paragraphs based on the data available. In order to make a better estimate of vertical flux and travel time, vertical profiles of hydraulic conductivity are needed. As shown in Figure 8 , the thickness and hydraulic conductivity of individual layers can be used to calculate the effective vertical hydraulic conductivity of the ensemble of layers.
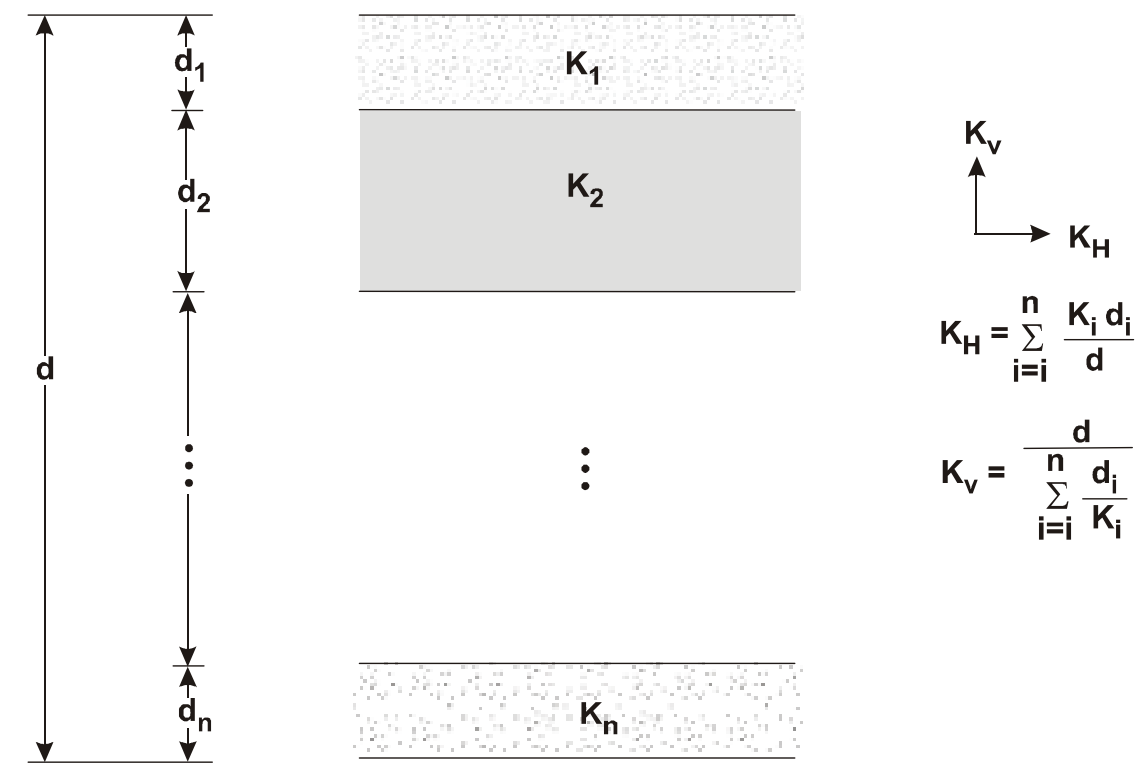

Figure 8. Effective vertical and horizontal hydraulic conductivity for a horizontally layered system (modified from Freeze and Cherry 1979). 
To estimate the vertical flux from the Boulder Zone into the overlying Upper Floridan Aquifer, the Darcy equation was used. The Darcy equation is

$$
q=-K \frac{d h}{d l}
$$

where

$$
\begin{array}{lll}
\mathrm{q} & = & \text { flux }\left[\mathrm{L}^{3} \mathrm{~L}^{-2} \mathrm{~T}^{-1}\right] \\
\mathrm{K} & = & \text { hydraulic conductivity }\left[\mathrm{L} \mathrm{T}^{-1}\right] \\
\mathrm{h} & = & \text { hydraulic head }[\mathrm{L}] \\
1 & = & \text { flow path length }[\mathrm{L}] \\
d / d & = & \text { differential operator. }
\end{array}
$$

The parameter values used are

$$
\begin{aligned}
& \mathrm{K}=2 \times 10^{-4} \mathrm{~cm} \mathrm{~s}^{-1} \\
& \mathrm{~h} \text { in Boulder Zone }=96-\mathrm{ft}=29 \mathrm{~m} \\
& \mathrm{~h} \text { in Upper Floridan Aquifer }=35-\mathrm{ft}=11 \mathrm{~m} \\
& \begin{aligned}
1=(\text { depth of the top of the Boulder Zone }- \text { depth to the top of the Middle Confining Unit) } \\
=(2,746-\mathrm{ft}-1,890-\mathrm{ft}) \\
=856-\mathrm{ft} \\
=260 \mathrm{~m} .
\end{aligned}
\end{aligned}
$$

The hydraulic conductivity value used is representative of the measured values of the Lower Floridan Aquifer and is at the low end of the range measured in the Middle Confining Unit (Figure 6). Use of a low value will lead to small values of vertical flux and long travel times, and is therefore conservative.

The hydraulic head values are described in the previous section. The depth to the top of the Boulder Zone was assumed to be the top of the Boulder Zone test interval reported by Singh, Garcia-Bengochea, and Sproul (1980), and the depth of the top of the Middle Confining Unit was taken from Rust (1998a, Figure 4-5).

Substituting these values yields $\mathrm{q}=1.4 \times 10^{-7} \mathrm{~m}^{3} \mathrm{~s}^{-1} \mathrm{~m}^{-2}$, or $1.4 \times 10^{-7}$ cubic meters of water per second, per square meter (in plan view) of flow area.

The discharge of water through the Middle Confining Unit can be calculated by multiplying the vertical flux by the area through which flow is thought to occur. The area was assumed to be enclosed by a line $0.25 \mathrm{mi}$. from the site boundary (the area of review defined in 40 CFR 146.3). The Aquifer Exemption Petition for the South District Waste Water Treatment Plant, Dade County, Florida $(\mathrm{CH} 2 \mathrm{M}$ Hill 1995, p. 29) indicates that this area is approximately 4.5 square miles, which is equal to $1.2 \times 10^{7} \mathrm{~m}^{2}$. 
The discharge through the Middle Confining Unit is thus calculated as

$$
\begin{aligned}
\mathrm{Q} & =\mathrm{qA} \\
& =\left(1.4 \times 10^{-7} \mathrm{~m}^{3} \mathrm{~s}^{-1} \mathrm{~m}^{-2}\right)\left(1.2 \times 10^{7} \mathrm{~m}^{2}\right) \\
& =1.6 \mathrm{~m}^{3} \mathrm{~s}^{-1} \\
& =1,600 \mathrm{~L} \mathrm{~s}^{-1} .
\end{aligned}
$$

Converting from liters to gallons yields

$$
\begin{aligned}
\mathrm{Q} & =423 \mathrm{gal} \mathrm{s}^{-1} \\
& =25,000 \mathrm{gal} \mathrm{min}^{-1} \\
& =36,000,000 \mathrm{gal} \mathrm{day}^{-1} \\
& =36 \mathrm{MGD} .
\end{aligned}
$$

If vertical leakage is assumed to occur through a smaller area, then the discharge will be proportionally smaller. For example, if leakage is assumed to occur through a rectangle 6,000 -ft long by 3,000 - $\mathrm{ft}$ wide (the dimensions of the hydraulic head contour plots shown in the previous section, which is slightly larger than the injection well field), the area is $1.8 \times 10^{7}-\mathrm{ft}^{2}$ or $1.7 \times 10^{6} \mathrm{~m}^{2}$. This yields

$$
\begin{aligned}
\mathrm{Q} & =\left(1.4 \times 10^{-7} \mathrm{~m}^{3} \mathrm{~s}^{-1} \mathrm{~m}^{-2}\right)\left(1.7 \times 10^{6} \mathrm{~m}^{2}\right) \\
& =2.4 \times 10^{-1} \mathrm{~m}^{3} \mathrm{~s}^{-1} \\
& =240 \mathrm{~L} \mathrm{~s}^{-1} .
\end{aligned}
$$

Converting from liters to gallons yields

$$
\begin{aligned}
\mathrm{Q} & =63 \mathrm{gal} \mathrm{s}^{-1} \\
& =3,800 \mathrm{gal} \mathrm{min}^{-1} \\
& =5,400,000 \mathrm{gal} \mathrm{day}^{-1} \\
& =5.4 \mathrm{MGD} .
\end{aligned}
$$

These assumptions and calculations suggest that a substantial portion of the 100 MGD of wastewater that is injected into the Boulder Zone could migrate into the overlying Upper Floridan Aquifer.

The limitations to this analysis are due mainly to uncertainties in the extent that the hydraulic conductivity values used in calculations are representative of the true hydraulic conductivity. In particular, if there are laterally extensive and continuous zones that have hydraulic conductivity substantially lower than the value assumed for this calculation, then the vertical flux through the Middle Confining Unit would be less than the calculated value. Conversely, if there are additional high hydraulic conductivity pathways - either natural or man-made — through the Middle Confining Unit, then the flux would be higher than value calculated.

The information provided is insufficient to evaluate the extent to which the measured hydraulic conductivity values are representative of the actual values. To make this evaluation, review of the site stratigraphy (based on geophysical logs), the intervals tested, test procedures, and data analysis methods would be required. 
It is assumed that fractures are the major pathways for fluid flow through the Middle Confining Unit. In discussing transport through fractured rock, Freeze and Cherry (1979) state that values of effective porosity of fractured rock on the order of $1-0.001$ percent are not unusual. Larger values of effective porosity lead to slower velocity, for a given groundwater flux. In order to make a conservative (low) estimate of groundwater velocity (i.e. average linear porewater velocity), the effective porosity of the Middle Confining Unit was assumed to be at the upper end of this range (1 percent). The velocity of water moving through the Middle Confining Unit can be calculated by dividing the Darcy flux $\left(\mathrm{q}=1.4 \times 10^{-7} \mathrm{~m} \mathrm{~s}^{-1}\right)$ by the effective porosity of the material, to yield an average linear porewater velocity of $1.4 \times 10^{-5} \mathrm{~m} \mathrm{~s}^{-1}$.

The travel time of a conservative, non reactive solute through the Middle Confining Unit can be calculated by dividing the thickness of the Middle Confining Unit and Lower Floridan Aquifer (260 m) by the average linear pore water velocity $\left(1.4 \times 10^{-5} \mathrm{~m} \mathrm{~s}^{-1}\right)$ to yield a travel time of $1.9 \times 10^{7}$ seconds, which is equal to 210 days.

The calculation of travel time is subject to uncertainty in both the estimated vertical groundwater flux and the value of effective porosity. If it is assumed that the effective porosity is ten times the value used in the previous calculation, or 10 percent (which is the midpoint of the range for bulk permeability of non-karst limestone reported by Freeze and Cherry 1979), then the velocity would be slower by a factor of ten and the travel time would increase by a factor of ten to 2,100 days or about 6 years.

\subsection{Hydrogeologic Conclusions and Recommendations}

\subsubsection{Conclusions}

\section{Hydraulic Head}

- Hydraulic head is greater in the Boulder Zone than in the overlying monitoring zones (ca. 1,000-ft, 1,500-ft, and 1,800-ft) in the Upper Floridan Aquifer, and therefore the vertical direction of groundwater flow is upward from the Boulder Zone to the Upper Floridan Aquifer.

- Hydraulic head values measured at each monitoring level in the Upper Floridan Aquifer appear to be perturbed, presumably by some wells being shut-in and others discharging (purging). Hydraulic head is lower in a discharging well than it would be if that well were shut in and allowed to recover to steady state. These head perturbations make it difficult to interpret spatial patterns in head within and between monitoring layers.

- Hydraulic head values measured in the injection wells also demonstrates anomalous values, presumably resulting from either some wells being shut in and others being used for injection or from differences in the density of the fluid in different wells.

- $\quad$ Differences in fluid density between wells could account for the differences in head measured between wells.

\section{Hydraulic Conductivity}

- Hydraulic conductivity values available for review were measured in the Upper Floridan Aquifer, the Middle Confining Unit, and the upper portion of the Lower Floridan Aquifer, using packer tests. A single value was measured in the Boulder Zone using a pumping test. 
- The single measured hydraulic conductivity value for the Boulder Zone indicates that it is approximately two to four orders of magnitude more conductive than the Middle Confining Unit, and approximately three to four orders of magnitude more conductive than the upper portion of the Lower Floridan Aquifer. The extent that this value is representative of the Boulder Zone cannot be assessed because only a single measured value is available.

- $\quad$ The measured hydraulic conductivity values do not show that the Middle Confining Unit has lower hydraulic conductivity than the lower portion of the Upper Floridan Aquifer. The measured hydraulic conductivity of both zones is greater than $1 \times 10^{-4} \mathrm{~cm} / \mathrm{s}$, which is comparable to karst limestone or sand. For comparison, the hydraulic conductivity of shale (typically relied upon for confinement of injection zones) is $10^{-7} \mathrm{~cm} / \mathrm{s}$ or less (Figure 7), which is three orders of magnitude less than the measured hydraulic conductivity of the Middle Confining Unit.

- The measured hydraulic conductivity of the upper portion of the Lower Floridan Aquifer is generally less than that of the Middle Confining Unit. This suggests either that the upper portion of the Lower Floridan Aquifer is less permeable than the Middle Confining Unit, or that the hydraulic test data are not representative of one or both zones. The upper portion of the Lower Floridan Aquifer may be a confining layer at this site.

- $\quad$ The effective vertical hydraulic conductivity of a layered system controls vertical fluid migration. The effective vertical hydraulic conductivity of a layered system is dominated by the hydraulic conductivity of the lower conductivity layers and is relatively insensitive to the higher conductivity layers. The response of packer tests with long test intervals (such as those used to generate the data reviewed) that span multiple layers in a horizontally layered system is dominated by the high conductivity layers and is relatively insensitive to the lower conductivity layers. Therefore, it is possible that the measured hydraulic conductivity data set is biased, with the measured values being larger than the values of vertical hydraulic conductivity that control vertical fluid movement.

- $\quad$ The vertical flux of water from the Boulder Zone through the upper portion of the Lower Floridan Aquifer and the Middle Confining Unit and into the Upper Floridan aquifer was calculated using values of hydraulic conductivity measured at the site. In order to be conservative (i.e. to calculate low values), the hydraulic conductivity value used in the flux calculation was approximately equal the lowest values measured in these units. This calculation shows that approximately 5 to 36 million gallons per day could move from the Boulder Zone to the Upper Floridan Aquifer. For comparison, approximately 100 million gallons per day are injected.

- $\quad$ Travel times for a conservative solute from the Boulder Zone to the Upper Floridan Aquifer were calculated based on these flux values and assumed values of effective porosity. The assumed values are in the range for fractured rock. The calculated travel times are short enough that conservative contaminants could migrate into the Upper Floridan Aquifer in approximately 1 to 6 years.

- $\quad$ As discussed in Section 7, the geochemical data do not show a spatial pattern of contamination that is consistent with widespread upward migration of contaminated water through a highly permeable confining layer. From this, it can be inferred that the Middle Confining Unit and / or the upper portion of the Lower Floridan Aquifer is a better confining unit than indicated by the hydraulic conductivity data set reviewed. This implies that the hydraulic conductivity data set reviewed does not adequately describe the vertical hydraulic 
conductivity of the Middle Confining Unit and / or the upper portion of the Lower Floridan Aquifer.

- Much of the uncertainty in the flux and travel time estimated is due to uncertainty in the value of vertical hydraulic conductivity. If the true value of vertical hydraulic conductivity for the Middle Confining Unit is less than the measured value used in the calculations presented here, then the flux would be lower and the travel time would be longer than the values calculated here. Therefore, in order to build a better case that the Middle Confining Unit acts as an effective barrier to upward migration of fluids from the Boulder Zone, it must be shown that the effective vertical hydraulic conductivity of the Middle Confining Unit is less than the value used here.

\subsubsection{Recommendations}

\section{Hydraulic Head}

- $\quad$ Spatial patterns of hydraulic head at steady state conditions may be useful for detecting inadequately sealed wells, which may be indicated by anomalous head values. Therefore, it is recommended that all monitoring wells be shut in and allowed to reach steady state conditions, and then hydraulic head measured at each monitoring well and at the injection wells. Anomalous values on plots of head (similar to Figures 2 - 5) would be interpreted as indicating that a nearby well is inadequately sealed or that there is a different hydraulic connection between the Upper Floridan Aquifer and the Boulder Zone nearby.

- $\quad$ The density of fluid in the well must be considered in calculating hydraulic head from wellhead pressure measurements.

- $\quad$ Changes in the operation of injection wells may cause perturbations in hydraulic head in monitoring wells in the Upper Floridan Aquifer if there are inadequately sealed wells or if there are other hydraulic connections between the Boulder Zone and the Upper Floridan Aquifer nearby. Therefore, it is recommended that a program be developed and implemented in which each injection well is sequentially taken out of service and head is monitored in the injection and monitoring wells. Comparison of hydrographs for the injection wells and the monitoring wells may indicate monitoring wells that appear to be in good hydraulic communication with the Boulder Zone, which would be evidence that a nearby well is inadequately sealed or that that there is a different hydraulic connection between the Upper Floridan Aquifer and the Boulder Zone nearby.

- Wells that are suspected of leaking can be examined using a cement bond log, which measures the integrity of the annular seal between the casing and the formation.

\section{Hydraulic Conductivity}

The following recommendations are based on the assumption that the facility operator will be required to generate hydrogeologic data sufficient to demonstrate that the Middle Confining Unit and / or the upper portion of the Lower Floridan Aquifer provides confinement that is sufficient to prevent upward migration of fluids from the Boulder Zone into the Upper Floridan Aquifer. The approach outlined in the recommendations that follow is designed to generate data needed to calculate the effective vertical hydraulic conductivity of the confining unit(s) between the Boulder Zone and the Upper Floridan Aquifer. 
- As described in Section 5, use borehole geophysical data measured in new wells at the site, laboratory measurements on rock cores, and petroleum industry techniques to estimate the thickness and hydraulic conductivity of various zones in the Middle Confining Unit and the upper portion of the Lower Floridan Aquifer.

- Identify low hydraulic conductivity zones in the new wells via flowmeter logging in the Middle Confining Unit and the upper portion of the Lower Floridan Aquifer, which are completed open-hole. These tests are conducted by pumping water from either the upper potion of the well or the bottom of the well and measuring vertical flow in the well during pumping. In a plot of vertical flow in the well as a function of depth, the rate of change in flow with depth is proportional to the hydraulic conductivity of the formation as a function of depth. Low conductivity zones can be identified as portions of the flow versus depth plot in which the change in flow with depth is zero or very small.

- $\quad$ Conduct a series of packer tests in discrete low hydraulic conductivity layers identified from interpretation of borehole geophysical logs and borehole flowmeter logs.

- Calculate the equivalent vertical hydraulic conductivity of the Middle Confining Unit and the upper portion of the Lower Floridan Aquifer using the layer thicknesses determined from interpretation of borehole geophysical logs and hydraulic conductivity values determined from laboratory analysis and field packer tests.

- Using the equivalent vertical hydraulic conductivity values and steady state head values, repeat the vertical flux and travel time calculations. Assess whether the predicted flux from the Boulder Zone into the Upper Floridan Aquifer will have a significant detrimental effect. 


\section{EVALUATION OF GEOCHEMICAL DATA}

This section reviews the chemical and isotopic data collected from the SDWTP site to evaluate evidence of vertical migration in the aquifer (Rust 1998c).

\subsection{Concentration with Depth}

Monitoring wells are completed in four depth zones in the injection field. These zones are referred to as the 1,000-ft zone, the 1,500-ft zone, the 1,800-ft zone, and the injection zone, which ranges from 2,300 to 3,000-ft bls. The major ion chemistry of the four zones shows significant differences. A graph of chloride concentrations with depth for all wells is provided in Figure 8. There is a general trend of increasing chloride concentration from $1,000-\mathrm{ft}$ to $1,800-\mathrm{ft}$ bls. The chloride concentrations at 1,800-ft are approximately the chloride concentration associated with seawater $(19,300 \mathrm{mg} / \mathrm{L})$. Concentrations of chloride in the injection zone are highly variable, but the highest concentrations in the injection zone are approximately as high as seawater. In some injection intervals, the injected effluent has completely replaced the initial formation water. In others, there is a mixing of effluent with the original formation waters. The deeper intervals of the injection wells show the smallest fraction of effluent. The difference in density is significant between the injected effluent and the pore water, and the effluent likely will float on top of the formation water. The higher chloride concentrations in the deeper zones of the injection wells support the conceptual model that density effects are a factor in the distribution of effluent within the injection interval.

At the 1,800-ft depth interval, three or four wells show a distinctly lower chloride concentration than the other wells completed at the same depth. Wells FAL11, FAL12, and FAL14 are significantly lower in chloride than the remaining wells. Well FAL10 is slightly lower in chloride than the main grouping of wells. At the 1,500-ft depth interval, the wells show a small range of chloride concentrations, but not the distinct difference seen at 1,800-ft.

Chloride concentrations in uncontaminated wells in the Boulder Zone and in the 1,800-ft zone are very similar to each other and are similar to seawater chloride concentrations. Above the 1,800-ft zone, chloride concentrations decrease toward the surface with relatively fresh water at the 1,000-ft interval. The similarity in water chemistry at 3,000-ft and 1,800-ft suggests some sort of connection between these two zones. On the other hand, the similarity of water chemistry also may reflect residual seawater emplaced into both zones long ago. A more rigorous review of regional trends in water quality and associated hydrology would help distinguish between these alternatives.

Ammonia concentration is an indicator of injectate and thus shows where contamination of groundwater by treated sanitary wastewater has occurred.. A graph of ammonia in groundwater with depth for all wells is provided in Figure 10. In the injection zone, a wide range of ammonia and chloride concentrations exists. The ammonia concentrations are inversely related to chloride: the wells with the highest chloride concentrations have the lowest ammonia concentrations. Maximum ammonia levels in the injection zone correspond to ammonia levels in the injected effluent.

In the 1,800-ft interval, ammonia levels are generally close to $0 \mathrm{mg} / \mathrm{L}$ with a few exceptions. Wells FAL10, FAL11, FAL12, and FAL14 contain elevated levels of ammonia. These are the same wells that contained lower levels of chloride than the remaining wells at the 1,800-ft depth interval. Many of the wells completed in the 1,500-ft depth interval contain elevated levels of ammonia. There is no indication of contamination with ammonia at the 1,000-ft level. 


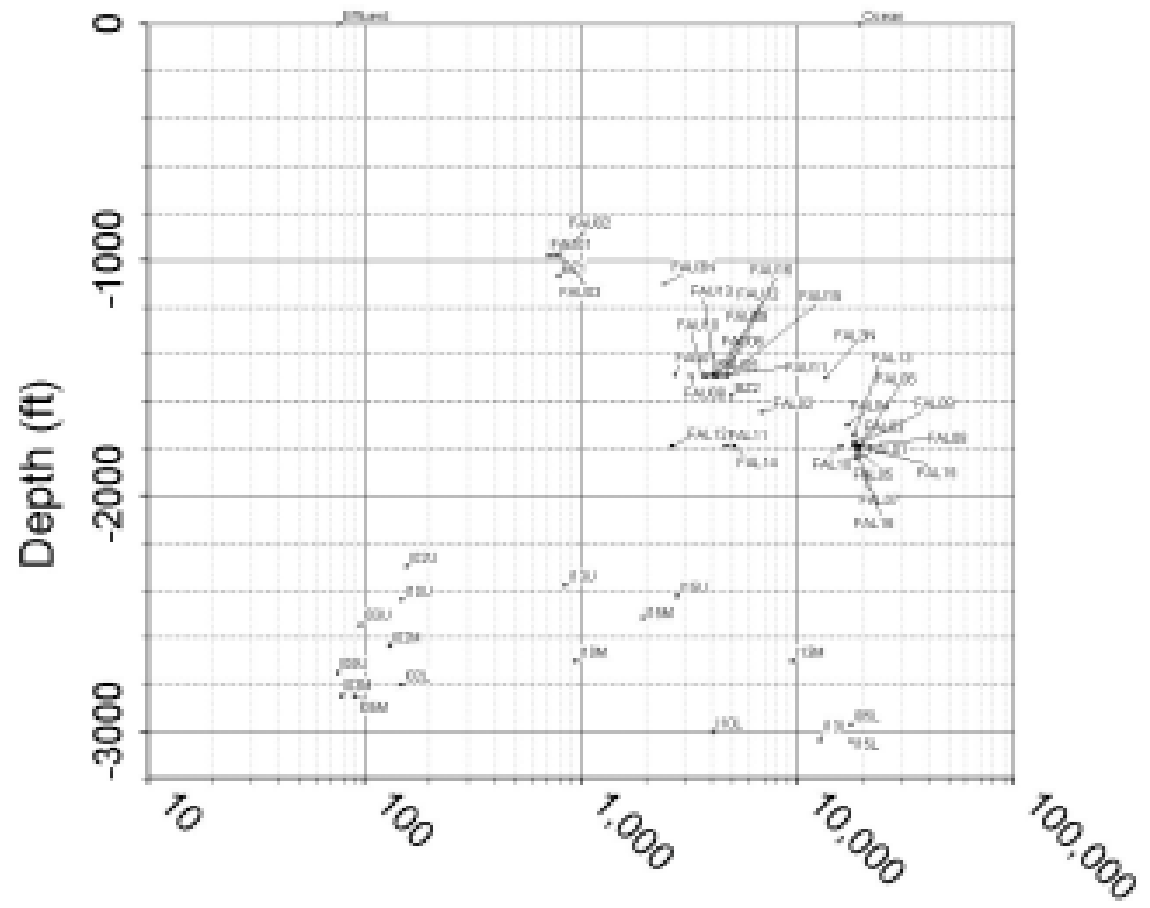

Chloride (mg/L)

Figure 9. Plot of chloride concentration with depth for all wells.

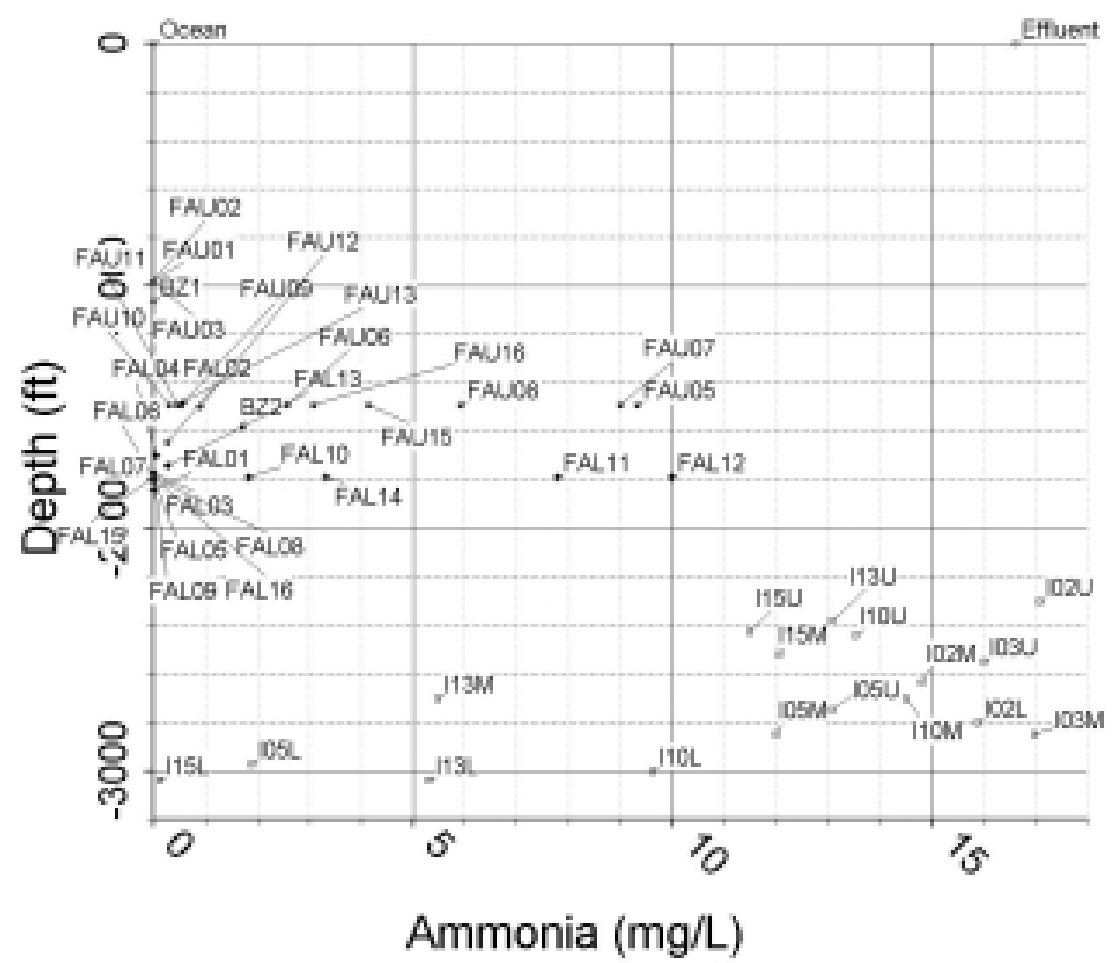

Figure 10. Plot of ammonia concentration with depth for all wells. 


\subsection{Spatial Distribution at $1,800-\mathrm{ft}$}

The spatial distribution in species at a depth interval may provide information on whether migration is localized or spread over a broad area. A map of wells completed at the 1,800-ft depth interval is provided in Figure 11, and the completion depths of the wells are shown in Figure 12. A map of the ammonia concentration at the 1,800-ft depth zone is provided in Figure 13. A map of the chloride concentration at the 1,800-ft depth zone is provided in Figure 14. Comparison of Figures 13 and 14 shows a high inverse correlation between chloride and ammonia. Wells with elevated ammonia levels are the same wells that have a decreased chloride concentration. From the spatial distribution of the concentrations, it appears that the contamination is related to point sources, rather than a widely distributed source. The conclusion from this distribution of ammonia and chloride in the 1,800-ft zone is that the contamination in this zone is not the result of widespread upward migration through the confining layer, but migration from point sources at or close to two or three wells. There are point sources at or near wells FAL14 and FAL 12. Contamination at Wells FAL10 and FAL11 could be originating near FAL12, or there also may be a lessor amount leakage at or near these wells.

\subsection{Spatial Distribution at $1,500-\mathrm{ft}$}

A map of wells completed at the 1,500-ft depth interval is provided in Figure 15, and the completion depths of the wells are shown in Figure 16. A map of the ammonia concentration at the 1,500-ft depth zone is provided in Figure 17. A map of the chloride concentration at the 1,500-ft depth zone is provided in Figure 18. The magnitude of the chloride concentrations in the 1,500-ft depth interval is much lower than the magnitude in the concentrations in the $1,800-\mathrm{ft}$ depth interval. In the $1,800-\mathrm{ft}$ interval, a distinct difference exists in chloride concentration between wells with ammonia and wells without. No such obvious relation is indicated in the 1,500-ft zone. A large variation in ammonia exists, but very little variation in chloride. The levels of ammonia are elevated in the northeast and northwest portions of the facility. The distribution at this level is not as clear as at the $1,800-\mathrm{ft}$ depth interval. Point sources appear to be present in the northeast and northwest. However, some level of contamination has spread throughout the 1,500-ft zone. Note that these point sources are not located at the BZ well cluster, and thus pre-1995 leaks in BZ-3 or BZ-4 do not appear to be the only source of contamination in the $1,500-\mathrm{ft}$ horizon.

\subsection{Mixing Relationships}

Three sources of water are clearly present in the subsurface. One is the original brine in the formations with a composition that approximates seawater. A second source of water is the effluent (treated sanitary wastewater) injected into the subsurface. The simplified definition of these waters is that effluent contains $16.5 \mathrm{mg} / \mathrm{L}$ of ammonia and no chloride, while seawater contains 19,300 mg/L of chloride and no ammonia. Using these two end members, the fraction of effluent and seawater in each sample was calculated. The sum of the two fractions, however, did not add up to 1.0. Therefore, a third component of groundwater was defined as the fraction not explained by the sum of effluent and seawater. The third component was found to have a moderate level of chloride and no ammonia. This third component corresponds to shallow groundwater at the 1,000-ft depth interval. A trilinear diagram, illustrated in Figure 19, was developed with the three apexes defined as seawater (ocean), effluent, and shallow groundwater. The top apex represents effluent with no chloride and ammonia. The left apex represents ocean water or the deep brines in the Boulder Zone. The right apex represents shallow groundwater with no ammonia and a small amount of chloride.

Effluent and most of the injection zone waters fall near the upper apex of the triangle indicating that most of the initial brine has been swept from the upper portions of the injection zone. Ocean water, 
some of the lower injection zone waters, and most of the waters from the 1,800-ft zone plot near the left apex of the triangle. These are the original deep formation waters. The water samples collected from the $1,000-\mathrm{ft}$ zone representing shallow groundwater plot at the right apex of the triangle. Water samples from

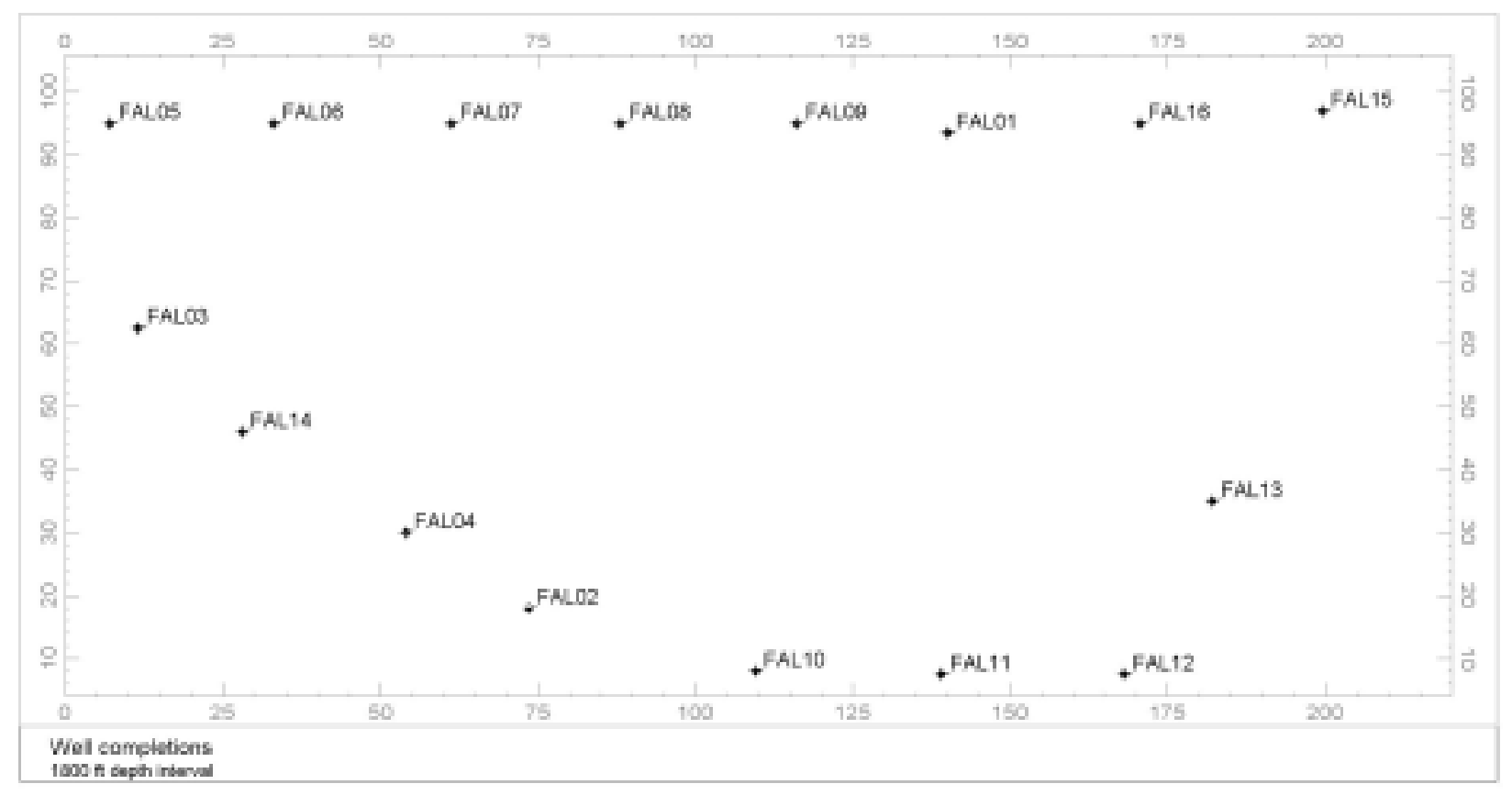

Figure 11. Map of wells completed in the 1,800-ft depth zone.

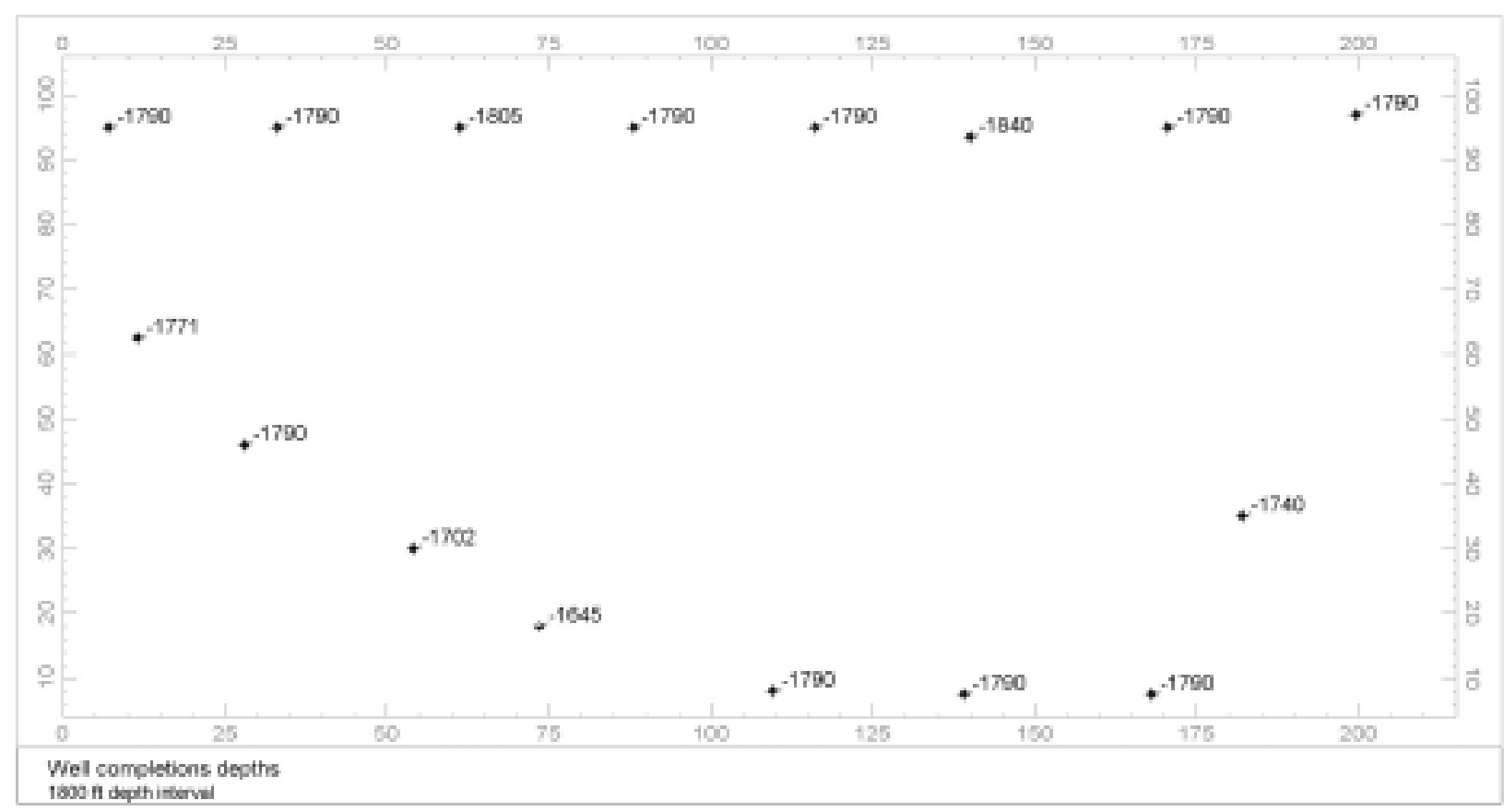

Figure 12. Map of wells completed in the 1,800-ft depth zone showing approximate completion depths $(\mathrm{ft})$. 


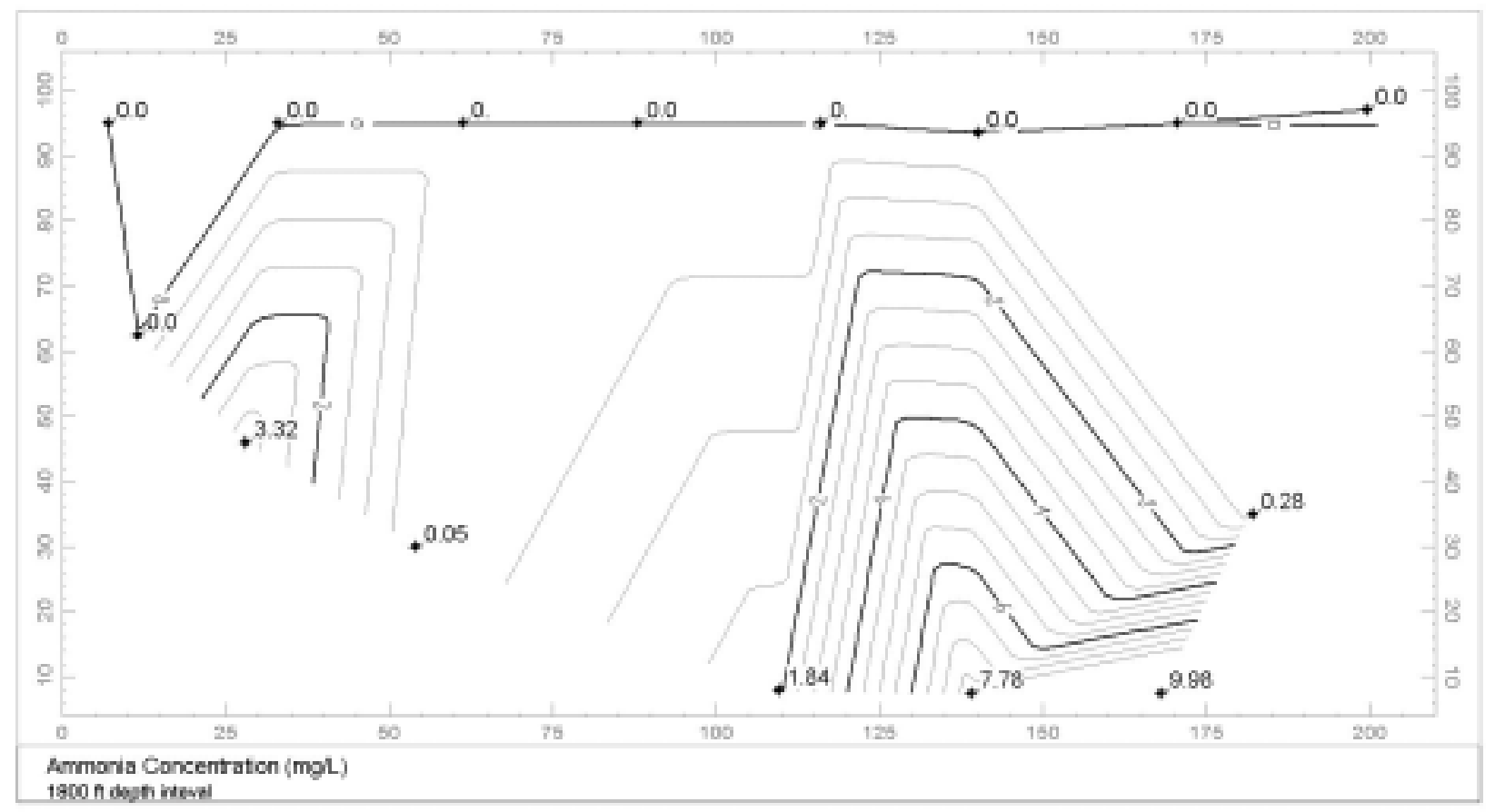

Figure 13. Map of the 1,800-ft depth zone showing the concentration of ammonia in wells.

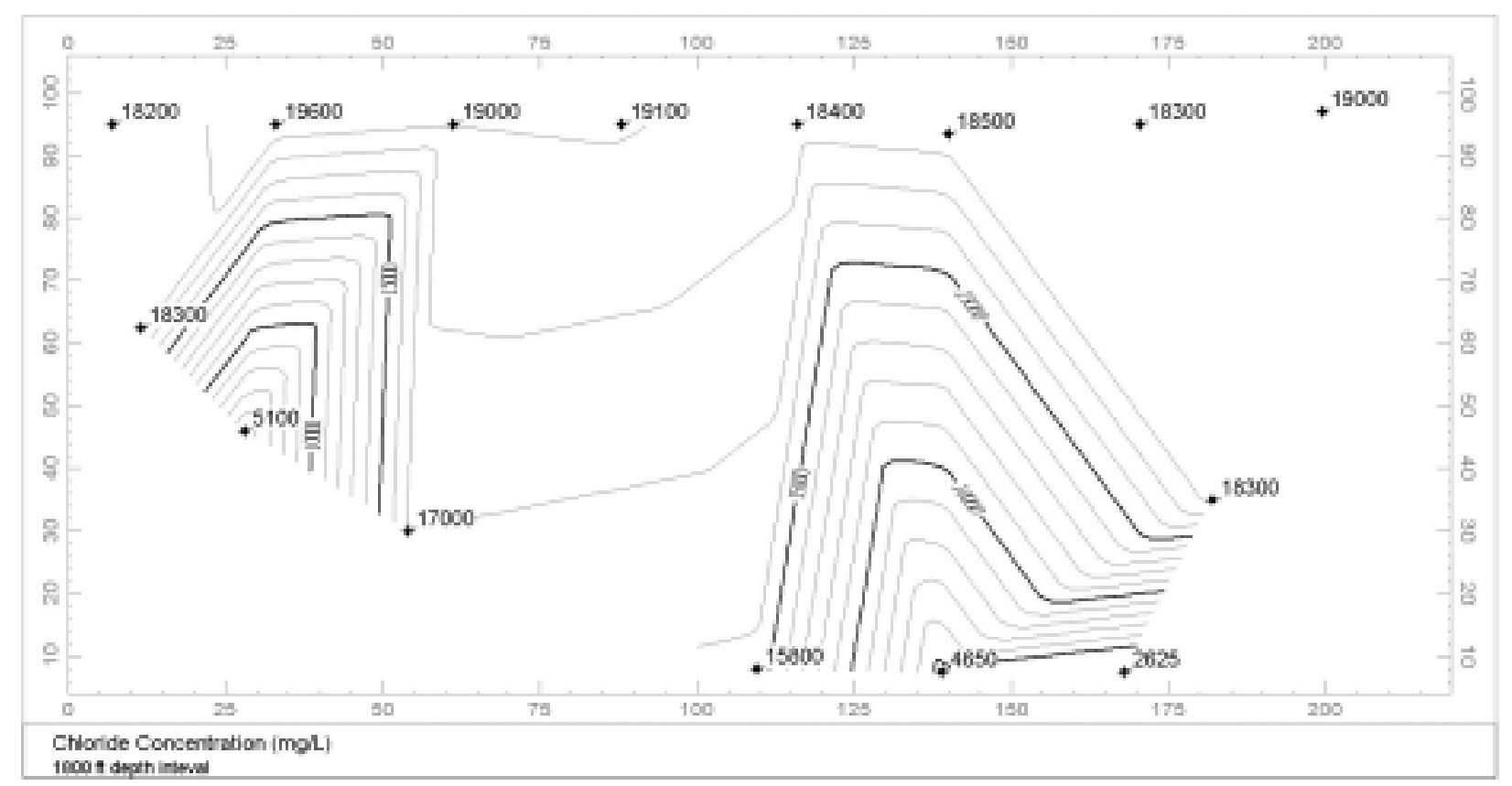

Figure 14. Map of the 1,800-ft depth zone showing the concentration of chloride in wells. 


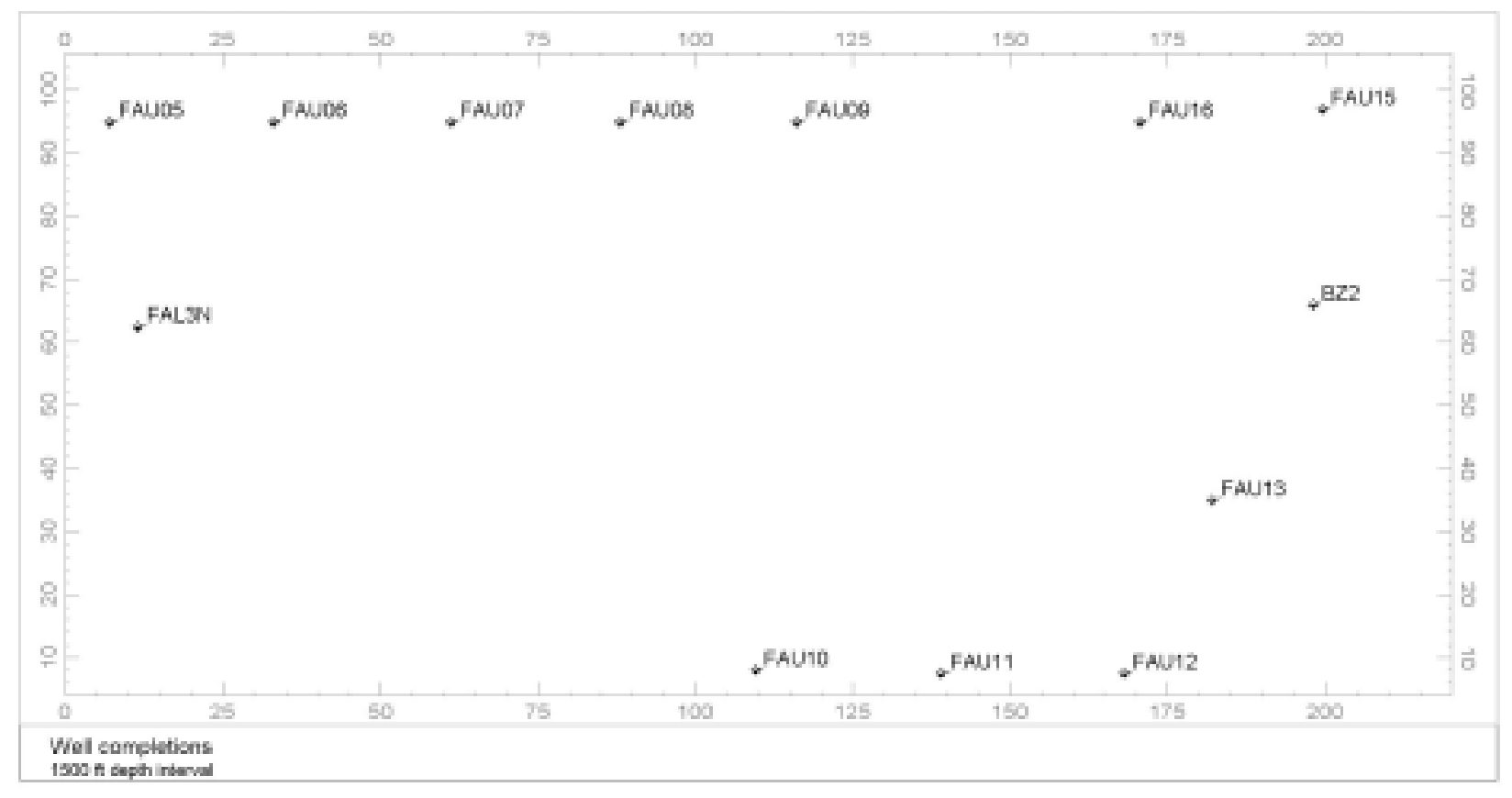

Figure 15. Map of the 1,500-ft depth zone showing locations of monitoring wells.

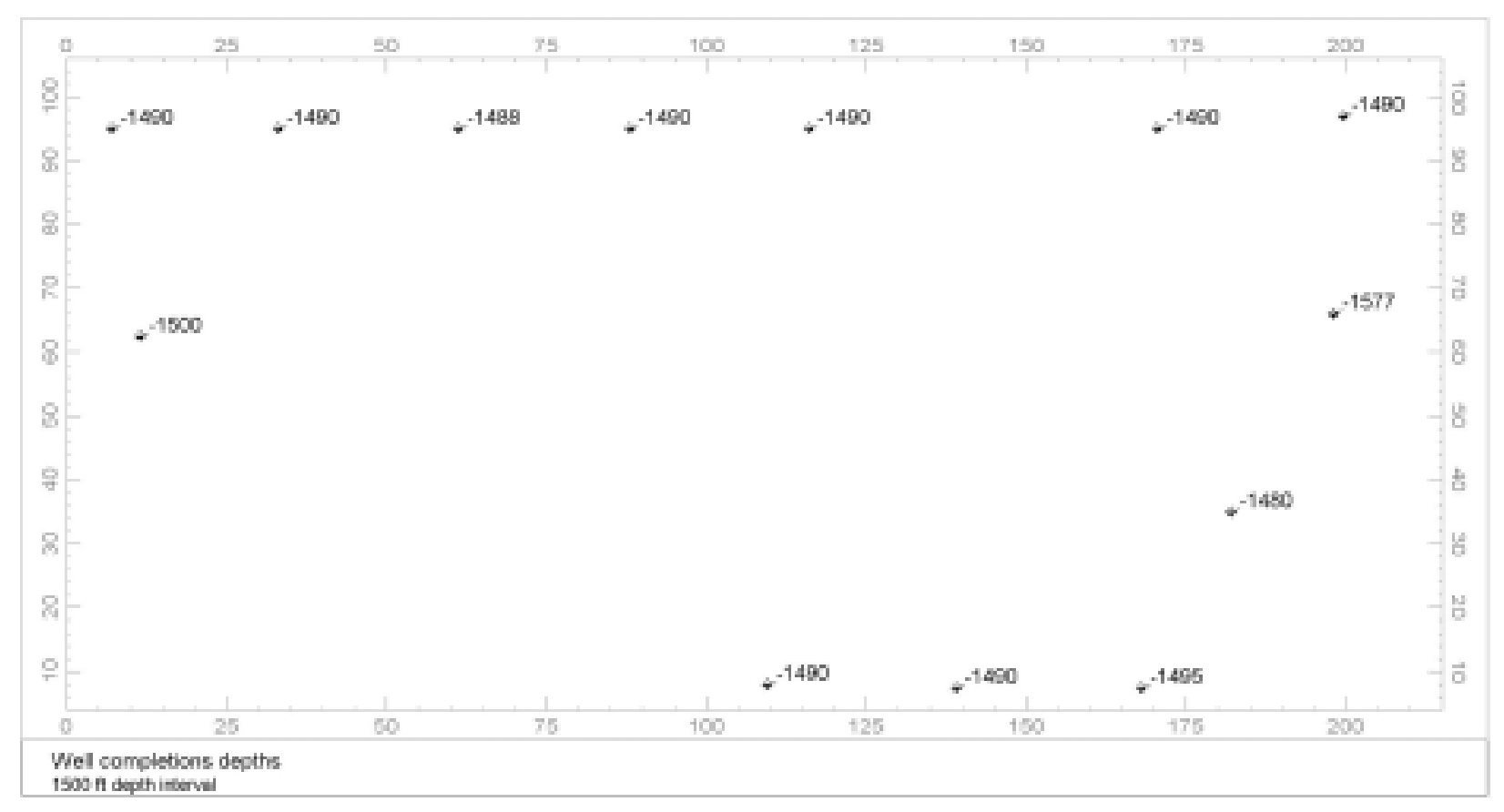

Figure 16. Map of the 1,500-ft depth zone showing depths of completion intervals (ft). 


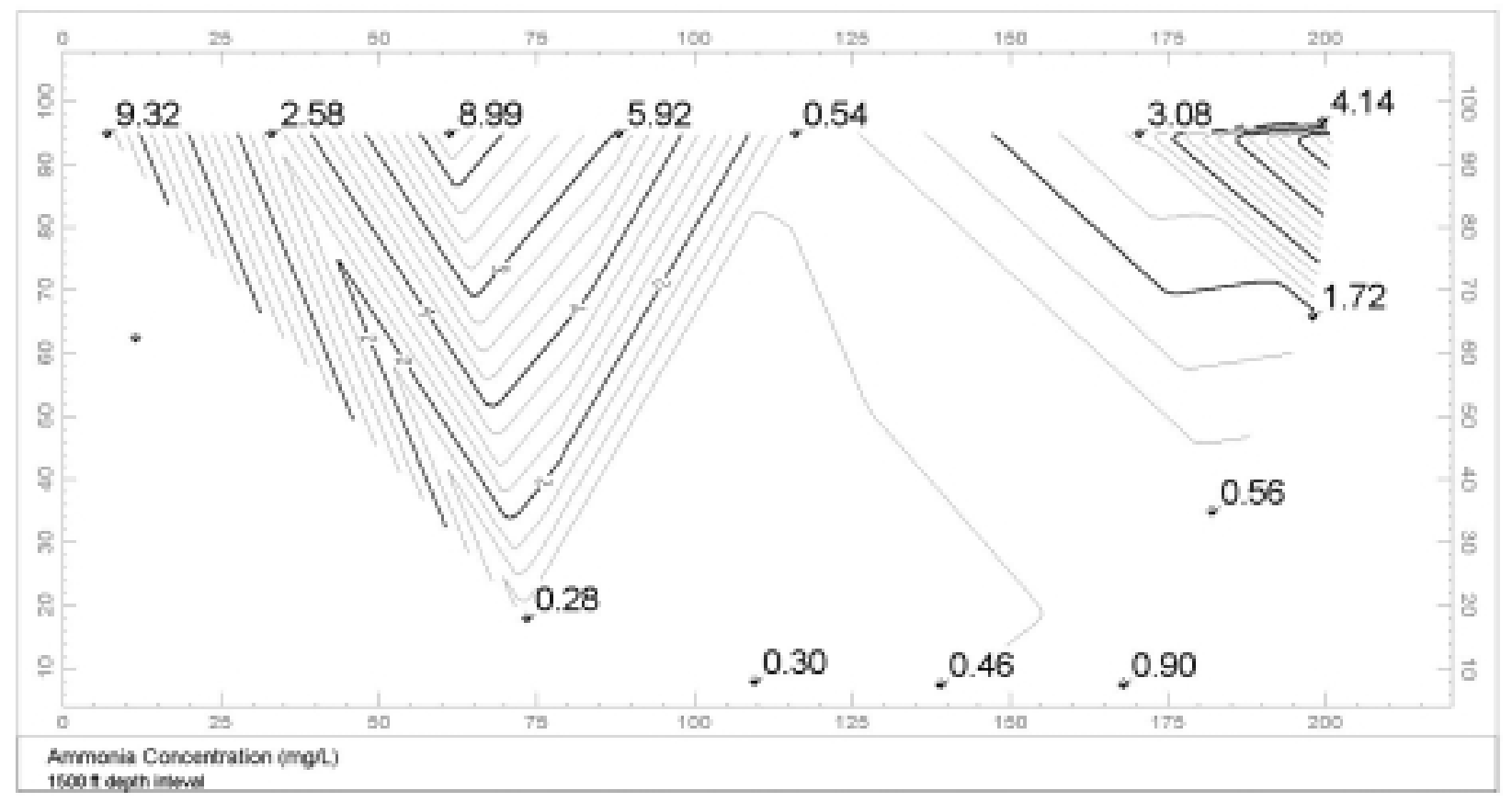

Figure 17. Map of the 1,500-ft depth zone showing the concentration of ammonia in monitoring wells.

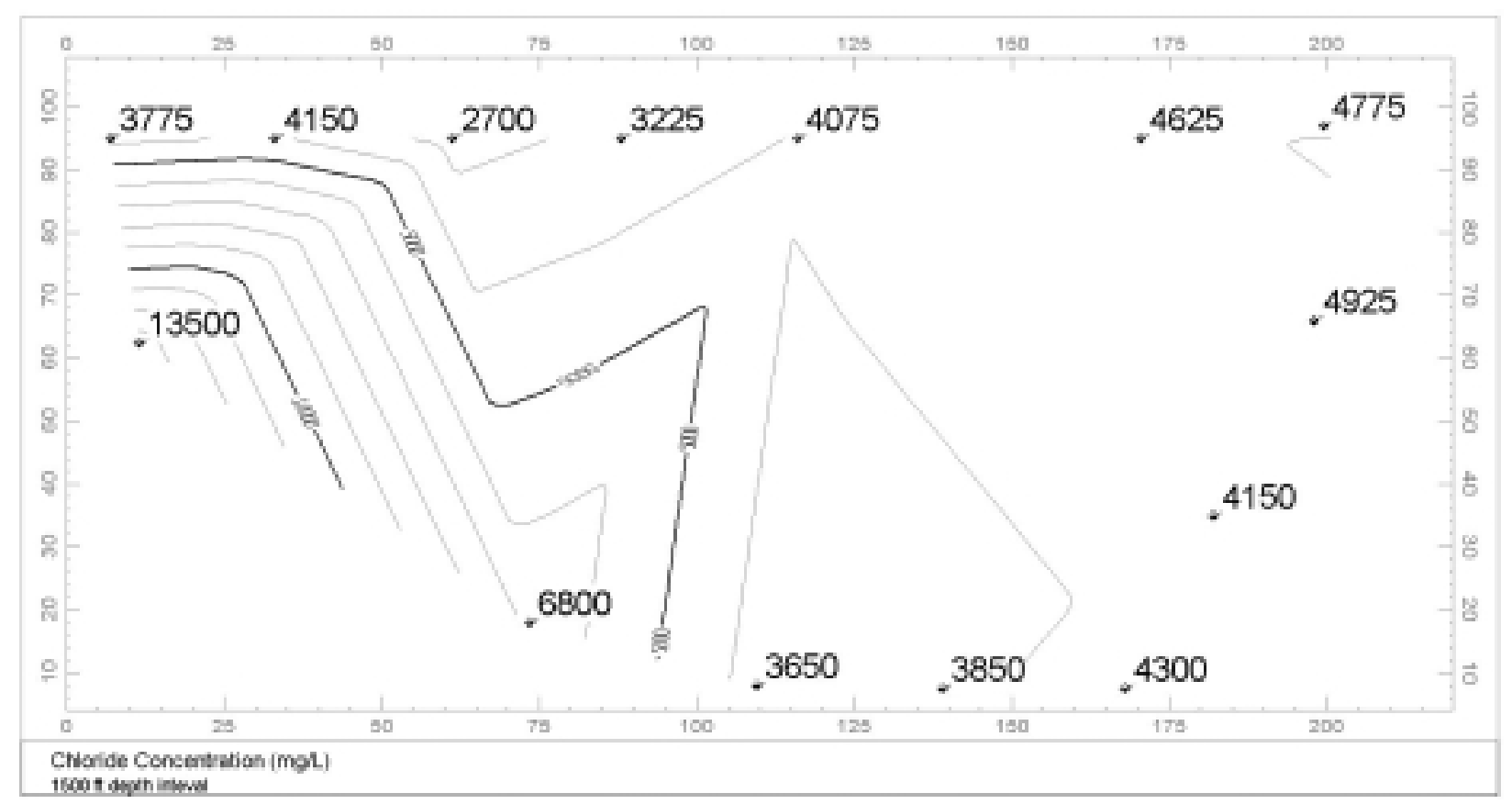

Figure 18. Map of the 1,500-ft depth zone showing the concentration of chloride in monitoring wells. 


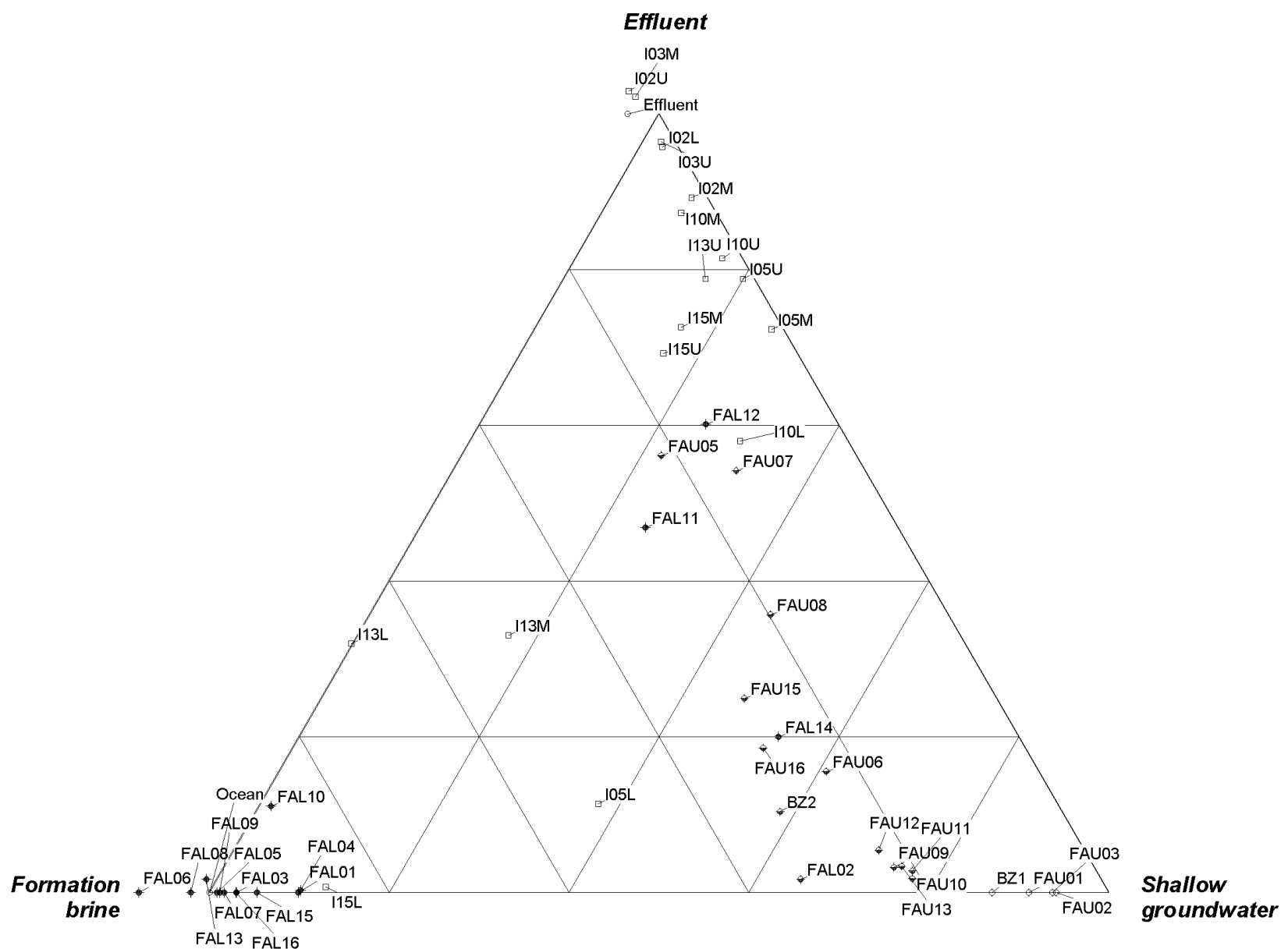

Figure 19. Ternary diagram showing the evolution of groundwater at the site from the mixing of three components.

the Upper Floridan Aquifer Wells FAU9 through FAU13 plot just to the left of the shallow groundwater apex indicating their composition is intermediate between the deep brines and the shallow fresh groundwater.

Waters in the 1,500 and 1,800-ft zones that showed evidence of contamination with effluent generally plot on a line between the effluent apex and the 1,000-ft zone samples. From the 1,800-ft zone, these samples are FAL12, FAL11, and FAL14. From the 1,500-ft zone, these samples are FAU05, FAU07, FAU08, FAU15, FAU16 and FAU06. Samples in the 1,500 and 1,800-ft zones lying on a line between effluent and the native water chemistry is a good indication of mixing of the two waters as an explanation of the source of contamination. The observation that the water samples from the 1,500 and 1,800 -ft zones fall along this same trend, and not on a mixing line between the effluent and shallow groundwater apexes, indicates that something more than mixing between effluent and shallow groundwater is taking place. The most likely explanation is that the water that migrated upward from the Lower Floridan Aquifer to the 1,800-ft zone is not strictly effluent, but effluent that has mixed with approximately $20 \%$ ocean water, similar to samples I15U, I15M, and I10L.

Another mixing relation can be seen in a plot of bromide concentration versus ammonia concentration as shown in Figure 20. Effluent and the samples from the injection zone plot along the right end of the $\mathrm{x}$ axis above $10 \mathrm{mg} / \mathrm{L}$ of ammonia. Bromide was not analyzed on many of the injection zone samples, and so the water in this zone likely does not have zero bromide. The effluent concentration also 
is in this area, indicating generally low bromide in effluent, and by extension, likely low bromide in the injection zone. Most of the 1,800-ft zone samples and ocean water plot along the y axis between 40 and $70 \mathrm{mg} / \mathrm{L}$ of bromide. Uncontaminated samples from the 1,000 and 1,500-ft zones lie along the bromide axis (little or no ammonia) between 0 and $25 \mathrm{mg} / \mathrm{L}$ of bromide. The contaminated samples from the 1,500 and 1,800-ft zones (FAL12, FAL11, FAL10, FAU05, FAU07, FAU08, FAU15, and FAU16) lie on a line between the high ammonia-low bromide injection zone samples and the low ammonia-high bromide brine samples. This supports the conclusion that the contamination in the Floridan Aquifer occurs by mixing of injected effluent with native groundwater.

\subsection{Geochemical Conclusions and Recommendations}

The following conclusions have been drawn from review of the geochemical data.

- Evaluation of water chemistry at the site shows that groundwater at the site includes three components: effluent (treated sanitary wastewater), native brine, and shallow groundwater.

- $\quad$ Mixing trends in water quality parameters support the conclusion that ammonia contamination in the Floridan Aquifer is from effluent.

- The vertical and spatial distribution of contamination in the Upper Floridan and Lower Floridan aquifers shows a pattern more consistent with point source contamination, such as leaking wells, than from widespread upward migration through a leaking confining layer. If contaminants were moving upward across a broad area through a leaking confining layer, contamination would probably be more widespread and concentrations would be higher in the 1,800-ft zone than in the 1,500-ft zone. In contrast, the observed contamination in the $1,800-\mathrm{ft}$ zone occurs in fewer wells than in the 1,500-ft zone; many wells in the 1,800-ft zone show no ammonia and have chloride concentrations consistent with the original native brine. Contamination is more widespread in the 1,500-ft zone, but there is still a distribution appearing to be "hot spots" around individual wells.

- The available data are not sufficient to differentiate between inadequately sealed wells or natural features as the point source contaminant features.

The following recommendation is based on review of the geochemical data.

- Investigate the integrity of wells that are contaminated with treated effluent, and adjacent wells. 


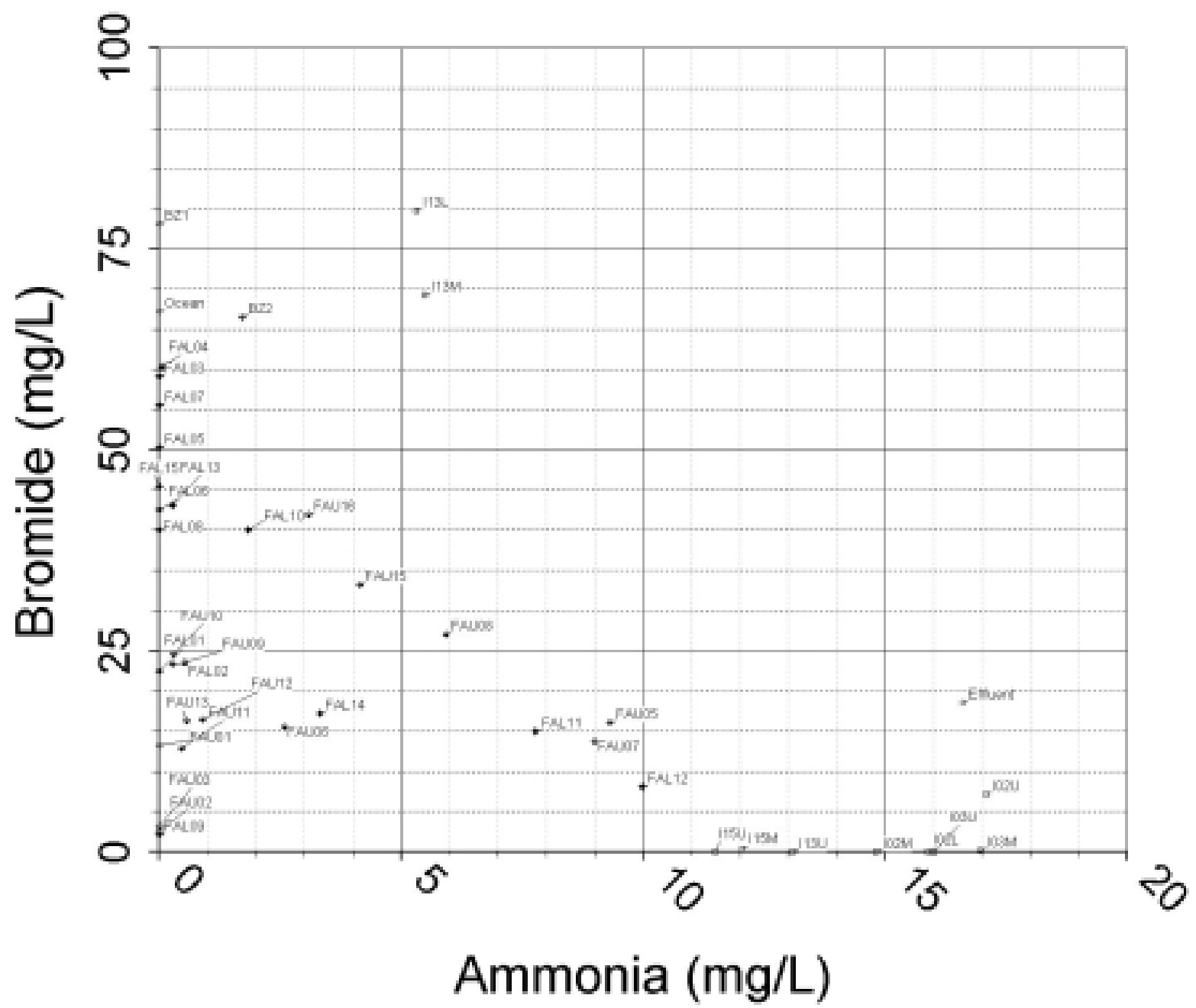

Figure 20. Graph of ammonia and bromide in groundwater samples. 


\section{SUMMARY OF CONCLUSIONS AND RECOMMENDATIONS}

The following overall conclusions have been drawn after reviewing the available information. Detailed conclusions are presented in Sections $5-7$.

- $\quad$ The geologic data provided for review are not sufficient to demonstrate that the Middle Confining Unit is a competent, low hydraulic conductivity layer that is capable of preventing upward migrations of fluids from the Boulder Zone into the overlying underground source of drinking water.

- The hydraulic head data available for review are inadequate to provide a useful understanding of the head relationships beneath the SDWTP because of the large spatial and temporal changes in head, presumably caused by purging of monitoring wells. The utility of this data set is further compromised because it is not known if corrections for variations in fluid density between wells have been made.

- The hydraulic conductivity data reviewed are not sufficient to demonstrate that the Middle Confining Unit is a competent confining layer. The data reviewed suggest that the upper portion of the Lower Floridan Aquifer has lower conductivity than the Middle Confining Unit, and thus it is possible that this zone may be an important confining unit.

- $\quad$ Based on the hydrogeologic data reviewed, widespread contamination of the Upper Floridan Aquifer would be expected. This was not observed, and therefore the degree that the hydrogeologic data reviewed are representative of conditions at the SDWTP must be questioned.

- The hydraulic conductivity data reviewed may not reflect the effective vertical hydraulic conductivity of the confining units above the Boulder Zone. If the actual vertical hydraulic conductivity were less than the reported values, then the degree of confinement of the Boulder Zone would be greater than the available hydrogeologic data indicate.

- The geochemical data reviewed indicate that groundwater in the Upper Floridan Aquifer is contaminated with treated wastewater.

- $\quad$ The spatial patterns of contamination in the Upper Floridan Aquifer are consistent with migration of contaminated water through isolated conduits, but are inconsistent with migration through the Middle Confining Unit throughout a broad area (as would be inferred from the hydrogeologic data). Isolated conduits could be either natural features or man-made features such as inadequately sealed wells.

The following general recommendations are made on the assumption that the facility operator will be required to generate geologic and hydrogeologic data sufficient to demonstrate that the confining layer above the Boulder Zone provides containment sufficient to prevent significant upward migration of fluids into the Upper Floridan Aquifer. These recommendations outline a program for obtaining these data. More detailed recommendations are presented in Sections $5-7$.

- Improve the geologic characterization of the SDWTP site by drilling new wells at the site, running a suite of borehole geophysical logs, analyzing core samples in the laboratory, and using petroleum industry techniques to determine the hydraulic properties of the confining units. 
- Improve the hydraulic head data set by measuring heads under steady state conditions and accounting for the density of fluid in well bores.

- Improve estimates of vertical hydraulic conductivity by identifying the low conductivity layers in confining units and measuring the hydraulic conductivity of discrete zones.

- Using the geologic and hydrogeologic data sets, reevaluate the competency of the confining units between the Boulder Zone and the Upper Floridan Aquifer.

The following activities are recommended to investigate the integrity of annular seals in wells that are suspected of leaking.

- Investigate the integrity of wells by sequentially removing injection wells from service and monitoring changes in hydraulic head in wells located nearby horizontally but at different depths.

- Examine wells suspected of having inadequate annular seals using borehole geophysical techniques.

- $\quad$ Repair or abandon wells found to have inadequate annular seals.

As discussed in Section 1, the specific questions that EPA Region 4 asked the INEEL to address are:

1. Whether the existing data are sufficient to either prove or disprove the presence of a confining layer above the zone of injection and, if it is present, whether it is capable of preventing movement of injected fluids from the zone of injection into the overlying monitoring zones.

2. Whether the data sets support the Miami-Dade Water and Sewer Department's contention that all of the observed contamination of the monitoring zone could have resulted from vertical flow through unsealed boreholes.

3. If the data are not sufficient to evaluate points 1 and 2, identify the additional data that should be collected to provide definitive answers.

The specific responses are shown below.

1. Neither the geologic nor hydrogeologic data sets are sufficient to show that a competent confining layer exists between the zone of injection and the Upper Floridan Aquifer. Although the confining layer above the Boulder Zone may in fact be competent, these data sets are not adequate to draw this conclusion.

2. The geochemical data sets indicate that groundwater at some locations in the Upper Floridan Aquifer is contaminated with treated wastewater, which implies that contaminants are migrating through the Middle Confining Unit. The spatial distribution of contamination in the Upper Floridan Aquifer is consistent with the presence of point sources but inconsistent with contaminant migration over a broad area. This suggests that isolated conduits, such as inadequately sealed wells or natural features, provide pathways for contaminated water to migrate upward from the Boulder Zone, but contaminants are not migrating upward through 
the Middle Confining Unit across a broad area. However, the data do not allow a distinction to be made between migration through inadequately sealed wells or through natural features.

3. Recommendations for collection of additional geologic and hydrogeologic data and for testing the integrity of wells that are suspected of having inadequate annular seals are provided in previous sections. 


\section{REFERENCES}

40 CFR 144.12, Code of Federal Regulations, Title 40, "Protection of Environment," Part 144, "Underground Injection Control Program," Subpart .12, "Prohibition of movement of fluid into underground sources of drinking water."

40 CFR 144.13, Code of Federal Regulations, Title 40, "Protection of Environment," Part 144, "Underground Injection Control Program," Subpart .13, "Prohibition of Class IV wells."

40 CFR 146.12, Code of Federal Regulations, Title 40, "Protection of Environment," Part 146, "Underground Injection Control Program Criteria and Standards," Subpart .12, "Construction requirements."

40 CFR 146.13, Code of Federal Regulations, Title 40, "Protection of Environment," Part 146, "Underground Injection Control Program Criteria and Standards," Subpart .13, "Operating, monitoring, and reporting requirements."

Florida Environmental Regulations, Article 528, "Water Regulations," Chapter 62-528, "Underground Injection Control."

CH2M Hill, 1995, Aquifer Exemption Petition for the South District Waste Water Treatment Plant, Dade County, Florida, CH2M Hill Inc. and TMG Inc.

Freeze, R. A., and J. A. Cherry, 1979, Groundwater, Prentice-Hall, Englewood Cliffs, New Jersey.

MDWSD, 1998, Mechanical Integrity Test and Results for Injection Well IW-2, Miami-Dade Water and Sewer Department, South District Wastewater Treatment Plant, Dade County, Florida.

MDWSD, 1994, "Packer Test Results," Attachment to Memorandum, from Miami-Dade Water and Sewer Department and CH2M Hill to Mr. Al Mueller, Florida Department of Environmental Protection Dade County Technical Advisory Committee Members, "Miami-Dade Water and Sewer Department South District WWTP Deep Well Injection System.”

Rust, 1998a, "Draft Supplemental to Report No. B-Geochemical Study Report Potentiometric Maps of the Floridan Aquifer and the Boulder Zone for South District Wastewater Treatment Plant, Dade County, Florida," Rust Environment \& Infrastructure Inc.

Rust, 1998b, Report No. 1: Chemical Tracer Feasibility Study, South District Wastewater Treatment Plant Deepwell Injection Field Miami-Dade County, Florida, Rust Environment \& Infrastructure Inc.

Rust, 1998c, Report No. 2-Geochemical Study Report for South District Wastewater Treatment Plant, Dade County, Florida, Rust Environment \& Infrastructure, Inc.

Singh, U. P., J. I. Garcia-Bengochea, and C. R. Sproul, 1980, "Deep Well Disposal of Secondary Effluent in Dade County, Florida,” Water Resources Bulletin, Vol. 16, No. 5, pp. 812-817. 


\section{Appendix A \\ Technical Documents Reviewed}


A-2 


\section{Appendix A}

\section{Technical Documents Reviewed}

CH2M Hill, 1995, Aquifer Exemption Petition for the South District Waste Water Treatment Plant, Dade County, Florida, CH2M Hill Inc. and TMG Inc.

MDWSD, 1998, Mechanical Integrity Test and Results for Injection Well IW-1, Miami-Dade Water and Sewer Department, South District Wastewater Treatment Plant, Dade County, Florida.

MDWSD, 1998, Mechanical Integrity Test and Results for Injection Well IW-2, Miami-Dade Water and Sewer Department, South District Wastewater Treatment Plant, Dade County, Florida.

MDWSD, 1998, Report No. A-Monitoring Well Purging Report for South District Wastewater Treatment Plant, Miami-Dade Water and Sewer Department, Dade County, Florida.

MDWSD, 1994, "Packer Test Results," Attachment to Memorandum, from Miami-Dade Water and Sewer Department and CH2M Hill to Mr. Al Mueller, Florida Department of Environmental Protection Dade County Technical Advisory Committee Members, "Miami-Dade Water and Sewer Department South District WWTP Deep Well Injection System.”

MDWSD, 1999, Monitoring Well Report for South District Wastewater Treatment Plant, Miami-Dade Water and Sewer Department, Dade County, Florida.

Rust, 1998a, Draft Supplemental to Report No. B-Geochemical Study Report Potentiometric Maps of the Floridan Aquifer and the Boulder Zone for South District Wastewater Treatment Plant, Dade County, Florida, Rust Environment \& Infrastructure Inc.

Rust, 1998b, Report No. 1: Chemical Tracer Feasibility Study, South District Wastewater Treatment Plant Deepwell Injection Field Miami-Dade County, Florida, Rust Environment \& Infrastructure Inc.

Rust, 1998c, Report No. 2-Geochemical Study Report for South District Wastewater Treatment Plant, Dade County, Florida, Rust Environment \& Infrastructure, Inc.

Singh, U. P., J. I. Garcia-Bengochea, and C. R. Sproul, 1980, "Deep Well Disposal of Secondary Effluent in Dade County, Florida," Water Resources Bulletin, Vol. 16, No. 5, pp. 812-817. 


\section{Appendix B \\ South District Wastewater Treatment Plant Injection Field Timeline}


B-2 


\section{Appendix B}

\section{South District Wastewater Treatment Plant Injection Field Timeline}

Table B-1. Injection field timeline.

\begin{tabular}{|c|c|}
\hline Date & Event \\
\hline 1977 (estimated) & $\begin{array}{l}\text { Hydraulic tests reported in Singh, Garcia-Bengochea, and } \\
\text { Sproul, (1980) performed by CH2M Hill on test hole drilled at } \\
\text { the South District Wastewater Treatment Plant (SDWTP). }\end{array}$ \\
\hline 1979 to 1981 & $\begin{array}{l}\text { Injection Wells I-1 through I-9 were constructed. Monitoring } \\
\text { Wells BZ, FA-1, FA-2 were constructed. }\end{array}$ \\
\hline $\begin{array}{l}\text { February 19, } \\
1983\end{array}$ & Injection commenced. Permitted capacity was 85 MGD. \\
\hline 1991 to 1992 & $\begin{array}{l}\text { Injection Wells I-10 through I-12 were constructed. } \\
\text { Monitoring Wells FA-3, FA-4 were constructed. }\end{array}$ \\
\hline $\begin{array}{l}\text { December 16, } \\
1992\end{array}$ & $\begin{array}{l}\text { Construction permit was issued for capacity expansion to } \\
\text { 112.5 MGD. }\end{array}$ \\
\hline 1993 to 1996 & $\begin{array}{l}\text { Injection Wells I-13 through I-17 were constructed. } \\
\text { Monitoring Wells FA-5 through FA-16 were constructed. }\end{array}$ \\
\hline 1994 & $\begin{array}{l}\text { Total dissolved solids (TDS) increase was detected in } \\
\text { Monitoring Well BZ "immediately above the injection zone at } \\
2,460 \text {-ft." } \\
\text { The casing of Monitoring Well BZ was found to be corroded at } \\
\text { approximately. 1,500-ft. }\end{array}$ \\
\hline
\end{tabular}

May 1994 Ammonia was detected in Well FA-5 (1,490 to 1,588-ft) at $7 \mathrm{mg} / \mathrm{L}$.

EPA 1997

Singh, Garcia-

Bengochea, and

Sproul 1980

Rust 1998b

EPA 1997

Rust $1998 b$

Rust 1998b

Rust 1998b

MDWSD 1999

MDWSD 1998b

Radioactive tracer test in Well IW-2 indicated a leak in the casing between 2,510 to 2,550-ft and an obstruction at 2,618-ft.

Radioactive tracer test confirmed the mechanical integrity of the cement surrounding the casing and the formation above 2,440-ft.

Video survey of Well IW-2 revealed a 3-ft separation in the casing at 2,516 to 2,519-ft and an obstruction at 2,627-ft. (There is neither evidence that the failed casing was repaired, nor that the well was removed from service. See September 15, 1998, entry).
MDWSD 1998b

MDWSD 1998b 


\begin{tabular}{llc}
\hline \multicolumn{1}{c}{ Date } & \multicolumn{1}{c}{ Event } & Reference \\
\hline 1994 & $\begin{array}{l}\text { Obstruction was detected in Well IW-2 at 2,620-ft. The well } \\
\text { was redrilled to remove the obstruction. } \\
\text { The gravel pack "collapsed." Debris (i.e., gravel and } \\
\text { formation) was removed. } \\
\text { The casing passed a pressure test. }\end{array}$ & \\
&
\end{tabular}

June 1994 First detection of ammonia above background in the 1,500-ft zone of Wells FA-5 through FA-8.

Rust 1998b

July 25, 1994 Dade County notified the Florida Department of Environmental

EPA 1997

Protection (FDEP) that ammonia and total Kjeldahl nitrogen

$(\mathrm{TKN})$ had been detected outside the injection zone.

August 30, 1994 Construction of facilities for expansion of the plant capacity to 100 MGD was completed.

1995

Monitoring Well BZ tubes 3 and 4 were closed and plugged.

Well BZ was reconstructed to monitor the 1,000 and $1,500-\mathrm{ft}$

zones.

EPA 1997

Rust 1998b

May 8, 1995 Construction began of Monitoring Well FA-11.

MDSWD 1998b

January 1996 Total Kjeldahl nitrogen analysis method was changed, resulting in slightly higher measured values.

February 1996 Sampling of Wells FA-10 through FA-16 at 1,500 and 1,800-ft commenced. Ammonia was detected as concentrations greater than $1 \mathrm{mg} / \mathrm{L}$.

late 1996 (?) $\quad$ Purging (i.e., allowing wells to flow via the artesian head) of the following wells commenced:

The upper zone Wells FA-5, FA-6, FA-7, FA-8, FA-15, FA-16

[Q $500 \mathrm{gpm}]$.

The lower zone Wells FA-11 and FA-12 [Q 70 gpm].

July to Nov 1997 All monitoring wells show a decrease in conductivity caused by defective conductivity meter, which was replaced in November 1997.

Rust 1998b

MDWSD 1999

MDWSD 1998c, 1999

EPA 1997

Dec 26, 1997 Consent order went into effect

MDWSD 1998c 


\begin{tabular}{|c|c|c|}
\hline Date & Event & Reference \\
\hline Jan 1998 & Well FA-5 Upper damaged and "killed." The well was placed & 1999 \\
\hline
\end{tabular}
back in service December 1998.

April 1998

A 1-week monitoring program was conducted for potentiometric data.

Rust 1998a

(Note: Atypical hydraulic conditions were observed.)

Sept 15, 1998 Video survey of Well IW-2 revealed a 7-ft split (2,516 -to 2,523-ft) in the casing.

MDWSD 1998b

(See May 13, 1994, entry for the first detection of the casing failure. It apparently was NOT repaired.)

Oct 9, 1998 Pressure test of Well IW-2 above 2,435-ft indicated that the casing integrity is satisfactory.

MDWSD 1998b

Oct 15, 1998 Video survey of Injection Well IW-1 "demonstrates visual mechanical integrity."

MDWSD 1998a

Oct 21, 1998 Pressure test of Well IW-1 was conducted above 2,583-ft. The well passed the test.

Oct 22, 1998 and Radioactive tracer test in Well IW - 2 proved inconclusive

Nov 21, 1998 above 2,485-ft. Possible tracer hit at 2,320-ft.

Oct 22, 1998 to Radioactive tracer test was conducted from Well IW-2 to

Nov 19, 1998 FW-11. A possible tracer hit was observed, despite poorly designed test configuration.

Nov 17, 1998 Radioactive tracer test of Well IW-1: “. . . resulted in no upward migration of the tracer behind the casing or the formation immediately surrounding the casing. The RTS demonstrates mechanical integrity."

MDWSD 1998a

MDWSD 1998b

MDWSD 1998b

MDWSD 1998a

March 12, 1999 Injection well operation permits were issued for Injection Wells MDWSD 1999 IW-1 through IW-3. 


\section{REFERENCES FOR TABLE B-1}

EPA, 1997, Findings and Administrative Order on Consent in the Matter of Metropolitan Dade County, on Behalf of Itself and Miami-Dade Water and Sewer Department, Docket No. 4-UICC-006-95, U.S. Environmental Protection Agency, Region 4.

MDWSD, 1999, Monitoring Well Report for South District Wastewater Treatment Plant, Miami-Dade Water and Sewer Department, Dade County, Florida.

MDWSD, 1998a, Mechanical Integrity Test and Results for Injection Well IW-1, Miami-Dade Water and Sewer Department, South District Wastewater Treatment Plant, Dade County, Florida.

MDWSD, 1998b, Mechanical Integrity Test and Results for Injection Well IW-2, Miami-Dade Water and Sewer Department, South District Wastewater Treatment Plant, Dade County, Florida.

MDWSD, 1998c, Report No. A-Monitoring Well Purging Report for South District Wastewater Treatment Plant, Miami-Dade Water and Sewer Department, Dade County, Florida.

Rust, 1998a, "Draft Supplemental to Report No. B-Geochemical Study Report Potentiometric Maps of the Floridan Aquifer and the Boulder Zone for South District Wastewater Treatment Plant, Dade County, Florida," Rust Environment \& Infrastructure Inc..

Rust, 1998b, Report No. 1: Chemical Tracer Feasibility Study, South District Wastewater Treatment Plant Deepwell Injection Field Miami-Dade County, Florida, Rust Environment \& Infrastructure Inc.

Singh, U. P., J. I. Garcia-Bengochea, and C. R. Sproul, 1980, "Deep Well Disposal of Secondary Effluent in Dade County, Florida," Water Resources Bulletin, Vol. 16, No. 5, pp. 812-817. 